Winter 2013

\title{
Lochner Disembedded: The Anxieties of Law in a Global Context
}

Peer Zumbansen

Osgoode Hall Law School York University, Toronto, pzumbansen@osgoode.yorku.ca

Follow this and additional works at: https://www.repository.law.indiana.edu/ijgls

Part of the International Law Commons, and the Transnational Law Commons

\section{Recommended Citation}

Zumbansen, Peer (2013) "Lochner Disembedded: The Anxieties of Law in a Global Context," Indiana Journal of Global Legal Studies: Vol. 20 : Iss. 1 , Article 3.

Available at: https://www.repository.law.indiana.edu/ijgls/vol20/iss1/3

This Symposium is brought to you for free and open access by the Law School Journals at Digital Repository @ Maurer Law. It has been accepted for inclusion in Indiana Journal of Global Legal Studies by an authorized editor of Digital Repository @ Maurer Law. For more information, please contact rvaughan@indiana.edu.

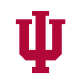

JEROME HALL LAW LIBRARY

$$
\text { INDIANA UNIVERSITY }
$$

Maurer School of Law
Blooming ton 


\title{
Lochner Disembedded: The Anxieties of Law in a Global Context*
}

\author{
PEER ZUMBANSEN ${ }^{+}$
}

\begin{abstract}
This paper explores, in an inevitably cursory manner, some of the main challenges facing a legal theory of transnational governance today. In part building on and responding to William Twining's identification of key problems of law in a global context (2009; 2012), the following paper adopts a two-fold approach. One element is to suggest a conceptual architecture, which captures law in its transformational state through a focus on actors, norms, and processes. Second, the paper proposes case

* This paper is based on a presentation at the 20th Anniversary event of the INDIANA JOURNAL OF GLOBAL LEGAL STUDIES (IJGLS), celebrated at Indiana University Maurer School of Law-Bloomington on April 5-6, 2012. It is inspired by and draws on ideas discussed over the years with IJGLS's founder and longstanding faculty advisor, Professor Fred Aman. In particular, the article further develops ideas that govern a forthcoming law school textbook on 'TRANSNATIONAL LAW: ACTORS, NORMS, PROCESSES,' authored by Aman and Zumbansen, to be published with LexisNexis. The article is further inspired by collaborative research carried out by the author, Andrea Ballestero (Rice University), Philip Liste (Hamburg), and Jothie Rajah (American Bar Foundation) on interdisciplinary global governance case studies. The author is immensely grateful to Daniel Drache, Marta Jankovic, Kirsten Mikadze, Jothie Rajah, and Hengameh Saberi, for excellent feedback on this paper, to Kellie Rockel, student editor-in-chief, and her colleagues at the IJGLS for their excellent editorial work, and to Indiana University and IJGLS for the opportunity to participate in the IJGLS Anniversary Symposium and for receiving very helpful comments from transnational colleagues joining him to mark the end of the second decade of one of the truly trailblazing journal undertakings in this field. Special thanks go to Fred Aman, who in his scholarship in administrative law, law and globalization, and democratic theory, as well as in his masterful directorship of the IJGLS has set standards for forward-looking and critical legal commentary, seeking to bridge the gaps between legal scholarship and the multidisciplinary investigations into the causes and consequences of globalization. His intellectual and humanistic leadership and IJGLS's first twenty years are an inspiration to all of us.

+ Professor of Law and Canada Research Chair in Transnational Economic Governance and Legal Theory, Osgoode Hall Law School, York University, Toronto and Director, Critical Research Laboratory in Law \& Society. State exam, PhD (Law), Habilitation (Frankfurt), Licence en droit (Paris X Nanterre), LL.M. (Harvard). Email: PZumbansen@osgoode.yorku.ca.
\end{abstract}

Indiana Journal of Global Legal Studies Vol. 20, Issue 1 (2013)

(C) Indiana University Maurer School of Law 
studies as a central methodological device to explore the nature, scope, and function of governance-both legal and nonlegal-in a global context. Through the identification of cases in global governance such as, but not limited to, examples of human rights violations around multinational engagements in developing countries or conflicts between indigenous peoples and the rights governing the extraction industry, as well as the role of nonstate actors in financial regulation, the essay engages with the structural and institutional changes that characterize legal regulation in a transnational context today. The paper posits the significance of identifying links between newly emerging, transnational cases and seminal cases from the nation-state experience in order to trace the continuance of dilemmas arising out of tough questions, old wounds, and hard cases. The U.S. Supreme Court's 1905 decision in Lochner v. New York serves as backdrop and reference for pertinent, but increasingly challenged, approaches to the identification of interests and rights in a social conflict.

\section{GLOBALIZATION AND THE LAW: HOW MANY UNKNOWNS?}

Compared to even just about ten or fifteen years ago, when scholars in law, sociology, or political science were able to list the term globalization among their research and teaching interests on their websites, today such announcements would likely strike us as quite naive. Despite the fact that globalization remains a term that continues to invite uncounted definitions and demarcations, ${ }^{1}$ for most scholars it has become less of a self-sufficient label to describe their research undertaking than a denotation of not only the context in which, but also a perspective from which a particular societal constellation is being addressed. This process of addressing a situation, a problem, or a challenge, however, already involves an act of selection, identification, and construction. It happens through the employment of analytical tools and instruments, through conceptual frameworks, and through particular forms and methods of organizing tools and frameworks to produce results. For a number of social sciences, in particular for law, sociology, ${ }^{2}$ political science, ${ }^{3}$ certain strands of economics, ${ }^{4}$

1. For a helpful orientation, see generally, JÜRGEN OSTERHAMMEL \& NIELS P. Petersson, Globalization: A Short History (Dona Geyer trans., 2005) (2003); MANFREd B. Steger, Globalization: A VERY SHORT INTRODUCTION (2003); Saskia Sassen, Globalization or Denationalization?, 10 REV. INT'L POL. ECON. 1 (2003).

2. See generally ULRICH BECK, WORLD AT RISK (Ciaran Cronin trans., 2009) (2007); SASKia SASSEN, A Sociology OF Globalization (2007).

3. See generally Michael Zürn, Globalization and Global Governance: From Societal to Political Denationalization, 11 EUR. REV. 341 (2003). 
anthropology, ${ }^{5}$ and political philosophy, ${ }^{6}$ as well as economic and social geography, ${ }^{7}$ globalization has led to a considerable complexification of the conceptual and disciplinary frameworks within which questions are being asked, data is being collected, and theories are being developed. In other words, globalization has a formidable function as it continues to be such a multifaceted "unknown," unfolding primarily through its short-circuiting of different disciplinary analyses and through its bringing together of previously demarcated issue areas and frameworks.

Today, law, as a discipline, theory, and practice can hardly be imagined outside of this context. Central to globalization's powerful impact on law is its radical challenge to the nexus between state and law, that is a challenge to the assumption that law emanates from authoritative, institutionalized processes grounded in a state-based system of norm creation, implementation, and adjudication. ${ }^{8}$ It is this nexus that has come under broad scrutiny, a development that finds expression in numerous iterations under titles such as Legal Order in a Global World, ${ }^{9}$ Global Legal Pluralism, ${ }^{10}$ or Transnational Law. ${ }^{11}$

4. See generally BRuno AMABLE ET AL., LES SYSTÈmES D'INNOVATION: À L'ÈRE DE LA Globalisation [INNOVATION Systems IN THE AGE of Globalization] (1997) (Fr.); Joseph E. STIGLiTz, Globalization and ITS Discontents (2002); Daniel Berkowitz, et al., Economic Development, Legality, and the Transplant Effect, 47 EUR. ECON. REV. 165 (2003); Dani Rodrik, Governance of Economic Globalization, in GovERNANCE IN A GLOBALIZING WORLD 347 (Joseph S. Nye Jr. \& John D. Donahue eds., 2000).

5. See generally AdDa B. BOzeman, The FUTURe OF LAW in a Multicultural World (1971); Partha Chatterjee, The Polittcs of the Governed: Reflections on PopUlar POLITICS IN MOST OF THE WORLD (2004); Sally Engle Merry, Anthropology, Law, and Transnational Processes, 21 ANN. REV. ANTHROPOLOGY 357 (1992); Annelise Riles, A New Agenda for the Cultural Study of Law: Taking on the Technicalities, 53 BUFF. L. REV. 973 (2005).

6. See generally SEYLA BENHABIB, ANOTHER COSMOPOLITANISM (Robert Post ed., 2006); Thomas PogGe, World Poverty and HUMan Rights (2d ed. 2008); IRIS Marion YOUNG, INCLUSION AND DEMOCRACY (2002).

7. See generally David Harvey, The Sociological and Geographical Imaginations, 18 INT'L J. POL. Culture \& Soc'Y 211 (2005); Paul Krugman, What's New About the New Economic Geography?, 14 OXFORD REV. ECON. POL'Y 7 (1998).

8. For a comprehensive engagement with this challenge, see WILLIAM TWINING, Globalisation AND Legal TheORY (2000). See also Neil Walker, Out of Place and Out of Time: Law's Fading Co-ordinates, 14 EDINBURGH L. REV. 13 (2010).

9. See Paul Schiff Berman, From International Law to Law and Globalization, 43 COLUM. J. TRANSNaT'L L. 485 (2005); Ulrich Sieber, Rechtliche Ordnung in einer Globalen Welt [Legal Order in a Global World], 41 ReChtSTHEORIE [THEORY OF JUSTICE] 151 (2010).

10. See Paul Schiff Berman, Global Legal Pluralism: A Jurisprudence of Law BEYOND BORDERS (2012); Paul Schiff Berman, Global Legal Pluralism, 80 S. CAL. L. REv. 1155 (2006); Ralf Michaels, Global Legal Pluralism, 5 ANN. REv. L. \& Soc. SCI. 243 (2009).

11. See generally PhILIP C. JEsSuP, TRANSNATIONAL LAW (1956); Alfred C. AMAN, JR. \& Peer Zumbansen, Transnational Law: Actors, Norms, Processes (forthcoming 
Notwithstanding their analytical and conceptual function, such frameworks are often accused of still failing to provide definitive answers as to the actual form, institutional structure, and relevance of law. In other words, attempts by lawyers to make sense of the globalization of law continue to struggle with competing contentions regarding the question of whether law should be seen as a victim and as collateral damage of an otherwise all-encompassing power that overwhelms and subdues nationally existing legal orders, ${ }^{12}$ or as a transformation science, through which the continuing differentiation processes of modern society can become manifest. ${ }^{13}$ Particularly the proliferation of private normmaking, which is the creation of legally binding rules outside of the institutional, state-based systems of rule setting, ${ }^{14}$ has led to a forceful accentuation of this dilemma. ${ }^{15}$ Seen

2013); Clive M. Schmitthoff, Nature and Evolution of the Transnational Law of Commercial Transactions, in 2 THE TRANSNATIONAL LAW OF INTERNATIONAL COMMERCIAL TRANSACTIONS 19 (Norbert Horn \& Clive M. Schmitthoff eds., 1982); Christian Tietje \& Karsten Nowrot, Laying Conceptual Ghosts of the Past to Rest: The Rise of Philip C. Jessup's 'Transnational Law' in the Regulatory Governance of the International Economic System, in PHILIP C. JESSUP's TRANSNATIONAL LAW REVISITED: ON THE OCCASION OF THE 50Th ANNIVERSARY OF ITS PUBLICATION 17 (Christian Tietje et al. eds., 2006); Peer Zumbansen, Transnational Law, Evolving, in ELGAR ENCYCLOPEDIA OF COMPARATIVE LAW 898 (Jan M. Smits ed., 2d ed. 2012).

12. Consider the parallels between this scenario and that drawn up by Carl Schmitt with regard to the state falling victim to society, an approach powerfully taken up by one of his most gifted pupils, Ernst Forsthoff. See Ernst Forsthoff, The Administration as Provider of Services, in WEIMAR: A JURISPRUDENCE OF CRISIS 326 (Arthur J. Jacobson \& Bernhard Schlink eds., Belinda Cooper et al. trans., Univ. of Cal. Press 2000). For more background, see Thomas Vesting, Die Sprengkraft des Heterogenen: Über Karl-Heinz Ladeurs Entwurf einer post-modernen Rechtstheorie [The Explosive Power of the Heterogenous Concept: On Karl-Heinz Ladeur's Design of a Post-Modern Legal Theory], 81 ARCHIV FÜR RECHTS- UND SOZIALPHILOSOPHIE [ARCHIVE FOR LEGAL AND SOCIAL PHILOSOPHY] 92 (1995) (Ger.); Ilse Staff, Die Wahrung staatlicher Ordnung: Ein Beitrag zum technologischen Staat und seinen rechten Propheten Carl Schmitt und Ernst Forsthoff [The Maintenance of Governmental Order: A Contribution to the Technological State and its Right-Wing Prophets Carl Schmitt and Ernst Forsthoff, 15 LEVIATHAN 141 (1987) (discussing the consequences of the concept of State under the increasingly dominant impact of modern technology, focusing on whether and how the threat to individual fundamental right positions within the technological State can be countered via its constitution) (Ger.).

13. See, e.g., Gunther Teubner, The King's Many Bodies: The Self-Deconstruction of Law's Hierarchy, 31 LAW \& Soc`Y REv. 763 (1997); Marc Amstutz, Global (Non-)Law: The Perspective of Evolutionary Jurisprudence, 9 GERMAN L.J. 465 (2008).

14. See generally TIM Büthe \& Walter Mattli, The New Global Rulers: The PRIVATIZATION OF REGULATION IN THE WORLD ECONOMY (2011).

15. For early examples of highly insightful analysis, see The EMERgence of Private AUTHORITY IN GLOBAL GOVERNANCE (Rodney Bruce Hall \& Thomas J. Biersteker eds., 2002); Private Authority and InTernational AfFaIRS (A. Claire Cutler et al. eds., 1999). 
against the background of the law-as-victim thesis, the ubiquitous forms of private ordering, both inside and outside of the nation state, are regularly read as further signs of the erosion processes, which allegedly characterize the general fate of the sovereign state in the global era and are now seen to find a particularly striking illustration in the relativization of the state's authority to administer and to control the institutions of norm creation. ${ }^{16}$ The emerging transnational landscape soon becomes a treacherous minefield of competing contestations brought forward by traditional and nontraditional actors. ${ }^{17}$ In a context that is characterized on the one hand by the significant entry of nonstate actors onto the transnational regulatory sphere, raising pertinent concerns regarding legitimacy and representation, ${ }^{18}$ and on the other hand by an important role still played by state regulatory institutions, ${ }^{19}$ the demarcation of spheres of influences, ${ }^{20}$ the identification of sources-as well as centers and peripheries-of power, ${ }^{21}$ or the mapping of newly emerging structures and spaces of

16. For a differentiated discussion of the continuing role of state function in a transformed landscape of international relations, see GOVERNANCE WITHOUT GOVERNMENT: ORDER AND CHANGE IN WORLD POLITICS (James N. Rosenau \& Ernst-Otto Czempiel eds., 1992); SASSEN, supra note 2 at 45-96.

17. For pertinent assessments from the perspective of public international law, see generally Luis Eslava \& Sundhya Pahuja, Between Resistance and Reform: TWAIL and the Universality of International Law, 3 TRADE L. \& DEV. 103 (2011); Balakrishnan Rajagopal, International Law and Social Movements: Challenges of Theorizing Resistance, 41 Colum. J. TranSNAT'L L. 397 (2003).

18. For critical assessments, see, for example, A. Claire CuTLER, Private PowEr AND Global authority: Transnational Merchant LaW in the Global Political Economy (2003); JACK L. GOLDSMITH \& ERIC A. POSNER, THE LIMITS OF INTERNATIONAL LAW (2005). For a persuasive critique of this position, see Paul Schiff Berman, Seeing Beyond the Limits of International Law, 84 TEX L. REv. 1265 (2006) (reviewing GOLDSMITH \& POSNER, supra); Oona A. Hathaway \& Ariel N. Lavinbuk, Rationalism and Revisionism in International Law, 119 HARV. L. REV. 1404 (2006) (reviewing GOLDSMITH \& POSNER, supra).

19. See Joseph E. Stiglitz, The Future of Global Governance, in THE WASHINGTON CONSENSUS RECONSIDERED: TOWARDS A NEW GLoBAL GoverNANCE 309 (Narcis Serra \& Joseph E. Stiglitz eds., 2008).

20. See ANNELISE RILES, THE NETWORK INSIDE OUT (2000) (exploring such demarcation).

21. For a post-"dependency theory" assessment of center/peripheriry tensions in global governance, historically associated with scholars such as Johan Galtung, e.g., Johan Galtung, A Structural Theory of Imperialism, 8 J. Peace Res. 81 (1971), and Immanuel Wallerstein, e.g., IMMANUEL WALLERSTEIN, WORLD-SYSTEMS ANALYSIS: AN INTRODUCTION (2004), see Craig Calhoun, Cosmopolitanism and Hegemony, in DEMOKRATIE IN DER WELTGESELLSCHAFT [DEMOCRACY IN THE WORLD SOCIETY] 17 (Hauke Brunkhorst ed., 2009) (Ger.). 
global sovereignty, 22 present formidable challenges, which can adequately be confronted only through an interdisciplinary analysis. Such an approach must ambitiously draw together historical and conceptual work in law, political science, sociology, anthropology, geography, and economics in an attempt to grasp the various voices and trajectories of analysis pertaining to the inchoate global order. In recent years, the label "global governance" has been applied to relating, complementing, and intersecting theoretical endeavours on the one hand, and to very real institutional transformations and policy implementations on the other. While scholars of different shades and colors engage in substituting globalization studies with ambitious analytical frameworks dedicated to studying "global governance," 23 the latter has long been a central reference point in global policymaking and in the exercise of institutional power. ${ }^{24}$ This congruence between scholarly imagination and conceptualization, on the one hand, and the actual institutional transformation on the other, prompts a follow-up question regarding the ability of the former to critically analyze and investigate the latter. In other words, the theoretical-conceptual work, pursued by a fast-growing group of scholars who are bringing their respective globally acquired expertise to bear on interdisciplinary collaboration, ethnographic fieldwork, and data mining, ${ }^{25}$ needs to pass muster when it comes to assessing these studies' sensitivity to the politics at the heart of these "global transformations."26

With the landscape of law's engagement with globalization thus sketched, the next task appears to be a more concrete one. In Part II, this paper reviews some pertinent disciplinary approaches to the study and analysis of transnational governance constellations, selectively and

22. See Saskia Sassen, The Places and Spaces of the Global: An Expanded Analytic Terrain, in Global.zation THEORY 79 (David Held \& Anthony McGrew eds., 2007).

23. See Global Governance: ETHICS AND ECONOMICS OF THE WORLD ORDER (Meghnad Desai \& Paul Redfern eds.,1995); RULing The WorLD?: ConstituTionalisM, INTERNATIONAL LAW, AND GLOBAL GovernanCE, (Jeffrey L. Dunoff \& Joel P. Trachtman eds., 2009); Allen Buchanan \& Robert O. Keohane, The Legitimacy of Global Governance Institutions, 20 ETHICS \& INT'L AFF. 405 (2006); Sally Engle Merry, Measuring the World: Indicators, Human Rights, and Global Governance, 52 CURRENT ANTHROPOLOGY S83 (2011).

24. See, e.g., RICHARD PeET, UNholy TRINITY: The IMF, World BANK AND WTO 2 (2003) ("[G]lobal governance institutions, such as the World Bank or the International Monetary Fund (IMF), might bring huge swathes of entire continents under the same pernicious, undemocratic control.").

25. For examples of recent studies, see ANNELISE RILES, Collateral KNowledge: LEGal REASONING IN THE Global FINANCIAL MARKETS (2011); ANNA LowENHAUPT TSING, FRICTION: AN ETHNOGRAPHY OF GLOBAL CONNECTION (2005).

26. The Global Transformations READER: AN INTRODUCTION TO THE GLOBALIZATION DeBATE (David Held \& Anthony McGrew eds., 2d ed. 2003). 
very cursorily considering law, political science, political philosophy, sociology, anthropology, geography, and history. Part III will suggest a number of translation categories between the national and the transnational legal imagination. In response to what seems to be a difficult choice either between a story of loss of law (of legal certainty, unity, and coherence) vis-à-vis the globalization of law or a story of the stubborn transposition of legal concepts developed on the national level onto the global one, the categories suggested here-actors, norms, and processes ${ }^{27}$-are drawn on in a attempt to highlight not only the links and continuities, but also the disruptions between national and transnational legal-regulatory configurations. That section will also engage with the framing concepts of jurisdiction and scale in order to highlight how governance conflicts are regularly disembedded by confining them to a particular context, governed by rules of competence and authority. The final section, Part IV, will return to the Lochner decision to discuss what possible lessons could be drawn today for present efforts to conceptualize transnational governance constellations. It is here where not only the links to, but also the differences between, cases such as Lochner and some of the emerging problem constellations become most evident. To the degree that the latter confront us with a complex array of interests, stakes, vulnerabilities, and entitlements of which the act of articulating, making visible, and judicializing is embedded in a particularly volatile situation marked by competing claims to institutional and normative authority, the task, for Dworkin's judge Hercules, ${ }^{28}$ for example, of drawing the right lessons from previous case law will become even more overwhelming.

\section{DISCIPLINARY EXHAUSTION AND THE "REAL WORLD"}

Transnational governance has been emerging as both a phenomenon and a field, which itself is constituted through an evolving and ambitious methodological agenda in response to a fast-evolving regulatory landscape. Legal theorists, philosophers, and sociologists of law have been prolific in attempting to ascertain the nature and scope of the challenges for law and jurisprudence from transformations commonly associated with globalization. William Twining, former Quain Professor of Jurisprudence at University College London, has been one such investigator into the prospects of law in today's changed

27. See generally Aman \& Zumbansen, supra note 11; Peer Zumbansen, The Future of Legal Theory, in THE LAW OF THE FuTURE AND THE FUTURE OF LAW 325 (Sam Muller et al. eds., 2011); Peer Zumbansen, Transnational Law, in Elgar ENCYClopedIA OF Comparative LAW 738 (Jan M. Smits ed., 2006).

28. See generally RONALD DWORKIN, LAW'S EMPIRE (1986). 
institutional and normative context. In his scholarship he has long been a traveler between worlds, depicting with a keen mind and an admirable sensibility the communication gaps that mark the space separating different legal (political and economic) cultures, ${ }^{29}$ sketching the dimensions of legal doctrine's engagement with globalization, ${ }^{30}$ highlighting the necessity to shift perspectives and viewpoints; ${ }^{31}$ to tirelessly revisit, reconsider; and to reassess the insights we have been gaining along this unpredictable path. ${ }^{32}$ Meanwhile, Twining has been a fervent advocate of the need to keep legal education, curricular reform, and law school innovation in close touch with these theoretical developments. ${ }^{33}$ In his 2009 Montesquieu lectures delivered at Tilburg Law School, building on his most recent major work, General Jurisprudence, ${ }^{34}$ he masterfully drew these different strands together and formulated an overseeable and yet highly complex list of challenges "identified inductively in over ten years of thinking about globalisation and law and general jurisprudence." 35 These challenges merit being reproduced here as they identify some of the central concerns of legal theory in the context of globalization in remarkable succinctness. Twining notes that:

the whole Western tradition of academic law is based on several kinds of assumptions that need to be critically examined in a changing context;

we lack concepts, and data to generalise about legal phenomena in the worlds as a whole: analytic concepts that can transcend, at least to some extent, different legal traditions and cultures;

comparison is the first step to generalisation and more sophisticated and expansive approaches to comparative law are critical for the development of a healthy discipline of law;

29. See William Twining, Other People's Power: The Bad Man and English Positivism, 1897-1997, 63 BROOK L. REV. 189 (1997).

30. See TwINING, supra note 8.

31. See Human RIGHTS, SOUTHERn VOICES (William Twining ed., 2009).

32. See William Twining, General Jurisprudence: Understanding LaW from a Global PeRsPeCtive (2009).

33. See TwINING, supra note 8 , at 257-63.

34. TWINING, supra note 32.

35. William TWINING, GLOBAIISATION AND LEGAL SchOLARSHIP 36 (2011). 
we need more sophisticated normative theories that are well-informed and sensitive to pluralism of beliefs and differences between value systems; and,

especially, we need improved empirical understandings of how legal doctrines, institutions and practices operate in the 'real world.' 36

While it is not possible in the narrow confines of the present paper to even attempt to do justice to the program of research, inquiry, and imagination Twining sets out for us, we may still want to underline the complexity of the constellation he identifies. His assessment of unchecked, yet influential assumptions, lacking analytic concepts, of the need to elaborate an adequately sophisticated theory of comparative legal studies and of more sophisticated normative theories reflects a sovereign grasp of a multilayered and difficult-to-grasp problem. But, this ambitious theoretical-intellectual agenda is accompanied by, and grounded and embedded in, a passionate call for improved empirical understandings of the real world workings of legal doctrines, institutions, and practices. What is striking in Twining's identification of the work to be done is, above all, the humility and caution with which the program is being formulated, which is why his depiction of law's challenges is so useful in setting the stage for a contemporary assessment of how law itself, and in exchange with other disciplines, sets its sails for this journey. There is, indeed, much to be humble and cautious about. The emerging and quickly overwhelming world of transnational governance needs to be treated as more than a new playground for well-worn and established rules, principles, and order concepts. Instead, law is very much faced with a multiplication of cases, which are characterized by a nontraditional quality of the actors, norms, and processes to which legal authority as well as legal rules have been associated. ${ }^{37}$ But, as Twining notes, there is not much security to be had in a world where lawyers (and others) witness the erosion of dearly held distinctions such as public/private, state/nonstate, and even law/nonlaw, prompting them to contemplate "law's fading coordinates." 38 Que faire, in such a situation?

36. Id. at 37 .

37. See HANDBOOK OF TRANSNATIONAL GoverNANCE: INSTITUTIONS AND INNOVATIONS (Thomas Hale \& David Held eds., 2011) (bringing together individual studies on fifty-one distinct regulatory regimes in the area of transnational governance).

38. See Marc Amstutz, The Letter of the Law: Legal Reasoning in a Societal Perspective, 10 GERMAN L.J. 361 (2009); Walker, supra note 8. 
While the four challenges identified above are pertinent in directing our attention to the undone theoretical and conceptual work, the fifth one-improved empirical understandings of how legal doctrines, institutions, and practices operate in the real world-is key. In the search for an analytical framework for law in this new, transnational landscape of new actors, norms, and processes, it is improved empirical understandings that hark back to a dimension of law intimately linking the old and the new, the national and the transnational, and the global. Twining's pointer to law's operations in the real world is sensitive to the longstanding concerns among perceptive observers as well as real world inhabitants with law's and lawyers' blind-sidedness regarding the impact and consequences of legal decisions (or, of their absence). Taken up, predominantly, by legal sociologists, ${ }^{39}$ criminologists, ${ }^{40}$.or legal anthropologists, ${ }^{41}$ the disregard of law and its personnel for the temporality and effect of law's operation 42 is a crucial component of any attempt to ground and to contextualize law and its role and its relation to society. ${ }^{43}$ An insight from these engagements that carries particular significance for today's efforts in demarcating law's role in a context of disembeddedness is that conceptual elaborations of law must remain closely connected to an evolving methodology to test theoretical assumptions and presuppositions. ${ }^{44}$ This goes some way in explaining

39. See, e.g., Marc Galanter, Why the "Haves" Come Out Ahead: Speculations on the Limits of Legal Change, 9 LAW \& SoC'Y REV. 95 (1974).

40. See, e.g., MARIANA VAlVERde, LaW'S DREAM of A COMMON KNOWledge (2003).

41. See, e.g., Sally Falk Moore, Law as Process: AN ANTHropological approach (1978).

42. See generally Austin Sarat, Vitality Amidst Fragmentation: On the Emergence of Postrealist Law and Society Scholarship, in THE BLACKWELL COMPANION TO LAW AND SOCIETY 1 (Austin Sarat ed., 2004) (tracing the development of the study of law and society).

43. See generally, Mariana VAlverde, EVERYday LAW ON THE STREeT: CitY GOVERNANCE IN AN AGE OF DIVERSITY (2012) (evaluating the role of law in city governance on both a local and global scale); John Paterson \& Gunther Teubner, Changing Maps: Empirical Legal Autopoiesis, 7 SOC. \& LEGAL STUD. 451 (1998) (outlining an approach to developing an empirical understanding of legal autopoiesis); Peer Zumbansen, Law's Knowledge and Law's Effectiveness: Reflections from Legal Sociology and Legal Theory, 10 GERMAN L.J. 417 (2009) (discussing the present and future state of legal sociology and theory).

44. See, e.g., Stewart Macaulay, Elegant Models, Empirical Pictures, and the Complexities of Contract, 11 LAW \& SoC'Y REV. 507 (1977) (analyzing the fact that contract law has developed theoretical foundations based on litigation despite the fact that few contract disputes are resolved via litigation); Stewart Macaulay, Non-Contractual Relations in Business: A Preliminary Study, 28 AM. SOC. REV. 55 (1963) (analyzing the role that occupation plays in determining the amount of planning and legal action that takes place in the context of business). See also Marc Galanter, In the Winter of Our Discontent: Law, Anti-Law, and Social Science, 2 ANN. REV. L. \& SoC. SCI. 1 (2006) 
the degree to which today's legal sociological and legal anthropological scholarship on law and globalization is adamant about identifying and monitoring possible patterns of neglect, exclusion, and omission in connection to some models of global law, as they rapidly become fashionable. The critical response by scholars working within the Third World Approaches to International Law (TWAIL) realm ${ }^{45}$ to the proposal of Global Administrative Law ${ }^{46}$ is noteworthy in this regard, ${ }^{47}$ as is the scrutiny of the recent turn to indicators ${ }^{48}$ by global governance institutions such as the World Bank. ${ }^{49}$

\section{A. The Treacherous Promise of Distinctions}

Besides these mentioned theoretical and legal-sociological contentions, law's responses to global governance have been mobilizing some well-established frameworks. In that vein, we can perceive an intriguing echo of public and private law perspectives, from which lawyers aim to disentangle the confusing web of new institutions, hard/soft law, and nontraditional processes of rule-making. From a public law perspective, discontents have been highlighting, for example, the political outcomes and costs of the post-9/11 regulation of civil rights and liberties, ${ }^{50}$ of the Iraq War and the surrounding doubts as to its

(critiquing what the author perceives to be a prevailing, and unjustified, negativity towards the law).

45. For background, see, for example, James Thuo Gathii, Third World Approaches to International Economic Governance, in INTERNATIONAL LAW AND THE THIRD WORLD: RESHAPING JUSTICE 255 (Richard Falk et al. eds., 2008); Obiora Chinedu Okafor, Critical Third World Approaches to International Law (TWAIL): Theory, Methodology, or Both?, 10 INT'L COMMUNITY L. REV. 371 (2008).

46. See generally Benedict Kingsbury et al., The Emergence of Global Administrative Law, 68 LAW \& CONTEMP. PROBS. 15 (2005) (identifying the new field of Global Administrative Law and proposing next steps for its development).

47. See generally B.S. Chimni, Co-Option and Resistance: Two Faces of Global Administrative Law, 37 N.Y.U. J. INT't L. \& POL. 799 (2005) (evaluating the effect of Global Administrative Law from a third world perspective).

48. This is, of course, a variation of David Kennedy's magisterial treatment of international institutional development. David Kennedy, The Move to Institutions, 8 CARDOZO L. REV. 841 (1987).

49. See generally Galit A. SaRfaty, Values in TRanslation: Human Rights and the CULTURE OF THE WORLD BANK (2012) (evaluating the marginalization of human rights concerns within the World Bank); Merry, supra note 23 (exploring the use of indicators as representations of complex phenomena for the purposes of global governance).

50. See, e.g., Kim Lane Scheppele, Law in a Time of Emergency: States of Exception and the Temptations of 9/11, 6 U. PA. J. ConsT. L. 1001 (2004) (exploring the political reactions to exceptional events, particularly those of September 11, 2001). 
legality, ${ }^{51}$ and of the enduringly negative impacts of failing trade and climate control negotiations. ${ }^{52}$ Meanwhile, from a private law perspective, a lot of attention regarding the emerging transnational landscape has focused on the effects of wide-ranging privatization and transnationalization processes of core areas of social regulation. ${ }^{53}$ In response to a movement that had its origin in the decline of Western welfare-state regulatory governance, ${ }^{54}$ and eventually attained a global dimension through the Washington Consensus' mandate of deregulation and privatization, ${ }^{55}$ private law scholars have drawn on the insights of sociologists and anthropologists to effectively illuminate the nature and role of legal regulation in the fast-expanding regimes, now referred to as "transnational private regulatory governance." 56

51. See, e.g., Jürgen Habermas, Interpreting the Fall of a Monument, 4 GERMAN L.J. 701 (2003) (evaluating whether positive outcomes justify what the author believes to be an illegal war); Nico Krisch, International Law in Times of Hegemony: Unequal Power and the Shaping of the International Legal Order, 16 EUR. J. INT'L L. 369, 395 (2005) (discussing changes in international law expanding a nation's right to preemptive self-defense); Ed Morgan, Slaughterhouse-Six: Updating the Law of War, 5 GERMAN L.J. 525 (2004) (exploring the legal debate surrounding the Iraq War).

52. See, e.g., DANI RODRIK, THE GLoBAlization PARADOX (2011) (arguing for a new regime of globalization enabling greater cooperation among nations in trade negotiations with added protection for individual nations); RoBERTo MANGABEIRA UNGER, FrEE TRADE REIMAGINED: THE WORLD DIVISION OF LABOR AND THE METHOD OF ECONOMICS 7-24 (2007) (identifying many problems with modern attempts at reaching trade agreements and the inefficiencies that have resulted); Lorand Bartels, Trade and Human Rights, in THE OXFORD HANDBOOK OF INTERNATIONAL TRADE LAW 571, 578-83 (Daniel Bethlehem et al. eds., 2009) (analyzing the costs of trade agreements with regard to human rights).

53. See, e.g., Roger BlanPain \& Michele Colucci, The Globalization of Labour STANDARDS: THE SOFT LAW TRACK (2004) (evaluating the effects of transnationalization processes on labor standards); Adelle Blackett, Codes of Corporate Conduct and the Labour Regulatory State in Developing Countries, in HARD CHOICES, SOFT LAW 121 (John J. Kirton \& Michael J. Trebilcock eds., 2004) (analyzing the impact of nongovernmental organizations on the development of international labor regulations); Dieter Kerwer, Rules that Many Use: Standards and Global Regulation, 18 GoverNANCE: INT'L J. POL'Y, ADMIN., \& INSTITUTIONS 611 (2005) (discussing the role of private standard setters in financial markets and the possibility of, and opportunity for, democratic control of such standard setters).

54. For insightful depictions and narratives, see NikLAS LUHMANN, POLITICAL THEORY IN THE WELfare STATE (John Bednarz Jr. trans., Walter de Gruyter 1990) (1981); Gunther Teubner, Regulatory Law: Chronicle of a Death Foretold, 1 SOC. \& LEGAL STUD. 451 (1992).

55. See The Washington Consensus Reconsidered: Towards a New Global GovernanCE, supra note 19; David Levi-Faur, The Global Diffusion of Regulatory Capitalism, 598 ANNALS AM. ACAD. POL. \& Soc. SCI. 12 (2005).

56. See generally Symposium, The Challenge of Transnational Private Regulation: Conceptual and Constitutional Debates, 38 J. L. \& Soc'Y 1 (2011) (discussing and debating the foundations, norms, and problems of transnational private regulation). 


\section{B. Social Norms Lurking Beneath Law's Floorboards}

We can discern echoes of previous contentions not only regarding the regulatory area from where such voices make themselves heard: in other words, the intricate connections that can be discerned between global regulatory discourses and their alleged forerunners in the nation-state are not limited to the recurrence of institutional or procedural transformations such as those which we can identify through the lenses of deregulation and privatization..$^{57}$ Perhaps even more important for a better understanding of the connections between such globally and nationally occurring institutional transformations are their consequences for the surrounding regulatory environment. This can be illustrated by adopting a term central in two realms: first, in the current private law imagination of globalization, and second, in the legal-political imagination within the nation-state. The term in question is "social norms." Social norms are being referred to in both national contract, ${ }^{58}$ and transnational lex mercatoria (law merchant), ${ }^{59}$ discourses when it comes to discerning the primacy of actors' self-regulatory capacities on the one hand and the necessity to keep an intervening, overbearing judiciary and state apparatus at bay, on the other. It must be noted that an interest in social norms as instantiations of societal self-governance harks back to earliest work carried out by pioneers in sociology of law, legal pluralism, ${ }^{60}$ and administrative law, ${ }^{61}$ long before becoming a token in a polemical argument against state interventionism and free markets. But it is through the parallel reading of the claims for uninhibited contractual governance without contract law (nation-state based) within debates over "incompetent courts,"62 and

57. The analysis provided by Ulrich Sieber, supra note 9 , is very helpful in this regard.

58. See generally ERIC A. POSNER, LAW AND SOCIAL NORMS (2000); Robert E. Scott, The Death of Contract Law, 54 U. TORONTO L.J. 369 (2004).

59. See, e.g., EMMANUEL GAILLARD, LEgaL THEORY of INTERNATIONAL ARBITRATION (2010) (analyzing the practical consequences of legal theories underlying international arbitration).

60. See, e.g., Eugen Ehrlich, Grundlegung Der Soziologie Des Rechts (1913) (Ger.), translated in Eugene Ehrlich, Fundamental PRINCIPLES of THE Sociology of LAW (Walter L. Moll trans., Russell \& Russell 1962) (outlining the beginnings of a sociological approach to the law).

61. See, e.g., Louis L. Jaffe, Law Making by Private Groups, 51 HaRv. L. REv. 201 (1937) (exploring the ability of interested private groups to influence the development of law). For an excellent engagement with Jaffe's approach to administrative governance, see Daniel B. Rodriguez, Jaffe's Law: An Essay on the Intellectual Underpinnings of Modern Administrative Law Theory, 72 CHI.-KENT L. REV. 1159 (1997).

62. See POSNER, supra note 58, at 158. 
those for an autonomous legal order in the transnational sphere, ${ }^{63}$ that we can see more clearly the politics attached to these assertions. It is here where transnational governance, too often depicted mainly as a mere description of an increasingly complex institutional set-up, is arriving politically. Only through such a parallel reading and the short-circuiting of deregulation and privatization discourses as they unfold on the national and the transnational, or global, level is it possible to grasp the challenges facing a (political) legal theory of global governance.

\section{Fear of Falling}

Compressed into a relatively small space we can discern some of the central challenges to current legal thinking: under the impression of an unquestionably deep-running transformation of forms of public and private ordering in many of the West's highly industrialized states, lawyers seek to discern the contours of the new, transnational context in which these developments must be seen today. What they find are impressive accounts of globalization processes that prompt a great number of social science disciplines to fundamentally rethink their analytical categories and conceptual frameworks. In this context, legal scholars find that their own accounts of the growing limits of regulatory capacity in view of border crossing environmental or security concerns, for example, coalesce with observations made by political scientists, sociologists, geographers, or anthropologists regarding a fundamental decentralization and privatization of norm creation and legal-political decision-making. For law, to be sure, there is much at stake, as this multidisciplinary diagnosis strongly points to the need for lawyers to rethink the proper foundations, boundaries and-in fact-the nature of their object itself. In other words, the rich accounts of legal pluralism and nonstate-based norm creation, which are central to current depictions of the shift from government to governance, ${ }^{64}$ can be read as strong signals that law itself has an identity crisis, a crisis regarding its own nature and function. ${ }^{65}$ We have already seen, however, that such

63. See, e.g., GAILLARD, supra note 59 (arguing in favor of the practice of allowing transnational actors to choose their form of dispute resolution); KLAUS PETER BERGER, The Creeping Codification of THE NEW Lex MERCATORIA (2d ed. 2010) (tracing the codification of developing autonomous global and transnational economic law and the effects resulting from such codification).

64. A fascinating overview of fast-proliferating issue areas and transnational regulatory regimes is offered in THE HANDBOOK OF TRANSNATIONAL GovernancE: INSTITUTIONS AND INNOVATIONS, supra note 37.

65. See, e.g., BERMAN, supra note 10 (exploring the difficulties caused by the many different intersecting bodies of law and regulation, particularly on interstate actors). 
depictions of, effectively, a co-existence of legal and nonlegal forms of social regulation and of a complex overlap of public and private spheres of societal rule-making, are part of the central make-up of legal theory, as it evolves over time. That merits mention, particularly in a context where assertions regarding the difficulties associated with such inchoate regulatory landscapes are frequently linked to both acknowledgments of proliferating private governance actors on the one hand and sometimes acquiescent recognitions of the exhaustion of state regulatory power, on the other. ${ }^{66}$

\section{The Tools We Have Available, Just in Case We Need Them}

The following stocktaking of different disciplines' approaches to and imaginations of transnational governance can at best be cursory. Its function is, however, to point to some of the governing conceptions and preoccupations inherent to those disciplines that have been at the forefront of reorienting their analytical and conceptual frameworks in response to transnational governance phenomena. Among the disciplines briefly considered here are law, political science, sociology, anthropology, geography, and history. Aware of the pitfalls of such cursory stocktaking, we can only point to some questions pursued within these disciplines with regard to global governance challenges.

For law in a global context, perhaps the key question has been: Can there be law beyond the state? This highlights the state's prominence in the twentieth century and Western legal imagination, ${ }^{67}$ with a related question being: How does the state's role on the national level ${ }^{68}$ compare

66. For critical engagement with such assertions, see H.W. Arthurs, The Administrative State Goes to Market (and Cries 'Wee, Wee, Wee' All the Way Home), 55 U. TORONTO L.J. 797 (2005); Kerry Rittich, Functionalism and Formalism: Their Latest Incarnations in Contemporary Development and Governance Debates, 55 U. TORONTO L.J. 853 (2005).

67. See generally JENS BARTELSON, A GENEALOGY OF SOVEREIGNTY (1995) (analyzing how the concept of sovereignty has played a central role in the development of transnational relations and theories of international law); Louis Henkin, That "S" Word: Sovereignty, and Globalization, and Human Rights, Et Cetera, 68 FoRdHAM L. REV. 1 (1999) (addressing the negative effects that the concept of sovereignty has had in international relations).

68. See generally ThOMAS RISS-Kappen, CoOperation Among Democracies: THE EUROPEAN INFLUENCE ON U.S. FOREIGN POLICY (1995) (evaluating the ways in which foreign states exert influence over one another's national policies through alliances); Susan Strange, The Retreat of the State: The Diffusion of Power IN THE WorLD ECONOMY (1996) (analyzing the declining influence of the state in light of the rise of nonstate actors); Mark Aronson, A Public Lawyer's Responses to Privatisation and Outsourcing, in The Province of Administrative LAW 40 (Michael Taggart ed., 1997) (evaluating states' attempts to restructure government through privatization and 
to that on an international one?69 And, which role should be attributed to newly emerging actors? ${ }^{70}$ The state/law nexus has far-reaching consequences and predetermines the context and analytic force of conceptual distinctions, such as state/nonstate, law/'nonlaw', and national/global. A well-known example is the transnational law merchant with its largely self-regulatory arbitration regimes. ${ }^{71}$ More recent debates over the scope and function of a global constitutional legal order risk reinscribing the state/law question among optimists, ${ }^{72}$ skeptics, ${ }^{73}$ and fragmentationists. ${ }^{74}$ For political science and political

outsourcing); Carol Harlow, The 'Hidden Paw' of the State and the Publicisation of Private Law, in A SIMPLE COMMON LAWYER: ESSAYS IN HONOUR OF MICHAEL TAGGART 75 (David Dyzenhaus et al. eds., 2009) (discussing the reaction of national administrative law to the emerging influence of globalization).

69. See generally THE POWER OF HUMAN RIGHTS: INTERNATIONAL NORMS AND DOMESTIC CHANGE (Thomas Risse et al. eds., 1999).

70. See generally Philip Alston, The "Not-a-Cat" Syndrome: Can the International Human Rights Regime Accommodate Non-State Actors?, in NON-STATE ACTORS AND HUMAN RIGHTS 3 (Philip Alston ed., 2005) (elucidating the difficulty that arises in incorporating nonstate actors into a transnational legal framework, as well as the problem of defining such actors by what they are not).

71. See generally A. CLAIRE CUTLER, supra note 18; Berthold Goldman, Frontières du droit et 'lex mercatoria', [Boundaries of Law and 'Lex Mercatoria]13 ARCHIVES DE LA PhILOSOPhIE DE DroIT [ARChIVES OF THE PhILOSOPHY OF LAW] 177 (1964); Nikitas E. Hatzimihail, The Many Lives-and Faces-of Lex Mercatoria: History as Genealogy in International Business Law, 71 LAW \& CoNTEMP. ProBS. 169 (2008) (tracing the history, and outlining the shape, of lex mercatoria); Clive M. Schmitthoff, International Business Law: A New Law Merchant, 2 CuRRENT L. \& Soc. ProBs. 129 (1961); Gunther Teubner, Breaking Frames: The Global Interplay of Legal and Social Systems, 45 AM. J. CoMP. L. 149 (1997) (evaluating the complimentary and competing functions of lex mercatoria and more traditional forms of law); Zumbansen, supra note 11.

72. See, e.g., Michel Rosenfeld, Rethinking Constitutional Ordering in an Era of Legal and Ideological Pluralism, 6 INT'L J. CONST. L. 415 (2008) (arguing that a global legal order might be achieved from the many applicable legal structures by relaxing hierarchy and embracing inevitable inconsistency).

73. See, e.g., Anne Peters, The Merits of Global Constitutionalism, 16 IND. J. GLOBAL LEGAL STUD. 397 (2009) (addressing common criticisms of global constitutionalism and suggesting that it has significant merit); Alexander Somek, Die Verfassung im Zeitalter ihrer transnationalen Reproduzierbarkeit: Gedanken zum Begriff der Konstitutionalisierung [The Constitution in an Age of Its Transnational Reproductability: Throughts on the Concept of Constitutionalism], in STRUKTURFRAGEN DER EUROPÄISCHEN UNION [STRUCTURAL QUESTIONS FOR THE EUROPEAN UNION] 135 (Franzius et al. eds., 2011) (Ger.); Jeremy Waldron, Constitutionalism: A Skeptical View (N.Y. Univ. Sch. of Law Pub. Law \& Legal Theory Research Paper Series, Working Paper No. 10-87, 2012), available at http://ssrn.com/abstract=1722771 (expressing doubt about the general usefulness of constitutionalism as a legal theory).

74. See, e.g., Andreas Fischer-Lescano \& Gunther Teubner, Regime-Collisions: The Vain Search for Legal Unity in the Fragmentation of Global Law, 25 MiCH. J. INT'L L. 999 (2004) (outlining the consequences of a shift in the global legal regime from being centered on moralistic norms to a more fragmented system of competing regimes); Gunther 
philosophy, since Hobbes, the question of the nature and consequences of a transformation of sovereignty has been central. Mobilizing concepts

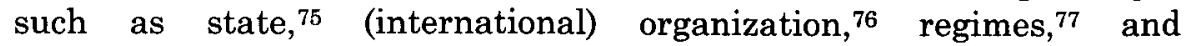
sovereignty, ${ }^{78}$ political science debates often fruitfully carve out the methodological challenge for a discipline incorporating a world of increased institutional fluidity and normative heterarchy into its analytical framework. ${ }^{79}$ Sociologists, locating society at the center of their analysis, have highlighted the historical contingency of the state

Teubner, Fragmented Foundations: Societal Constitutionalism Beyond the Nation State, in The Twilight of Constitutionalism? 327 (Petra Dobner \& Martin Loughlin eds., 2010) (identifying the fragmentation resulting from the emergence of private regulation and globalization and proposing solutions for states).

75. See generally R.B.J. WALKER, INSIDE/OUTSIDE INTERNATIONAL RELATIONS AS PolitiCal THeORY (1993); Léon Duguit, The Law and the State, 31 HARV. L. REV. 1 (1917) (analyzing the role of the state in the development of public law and questioning whether there is any higher organizing principle).

76. See generally José E. Alvarez, International Organizations: Then and Now, 100 AM. J. INT'L L. 324 (2006) (tracing the legal history and transnational role of international organizations); Friedrich Kratochwil \& John Gerard Ruggie, International Organization: A State of the Art on an Art of the State, 40 INT'L ORG. 753 (1986) (analyzing the disconnect between the vibrancy of the study of international organizations and their relative weakness in practice).

77. See generally INTERNATIONAL REGIMES (Stephen D. Krasner ed., 1983) (analyzing the structures and roles of international regimes).

78. See generally BARTELSON, supra note 67 (analyzing how the concept of sovereignty has played a central role in the development of transnational relations and theories of international law); ANNE-MARIE SLAUGHTER, A NEW WORLD ORDER (2004) (arguing that transnational law should reflect a new world order in which sovereignty is subservient to "government networks"); Thomas W. Pogge, Cosmopolitanism and Sovereignty, 103 ETHICS 48 (1992) (proposing the redrawing of borders to decrease the likelihood of interstate conflict).

79. See generally Kenneth W. Abbott \& Duncan Snidal, Strengthening International Regulation Through Transnational New Governance: Overcoming the Orchestration Deficit, 42 VAND. J. TRANSNAT'L L. 501 (2009) (proposing a new model of governance in order to account for the growing effects of nongovernmental actors); Kenneth W. Abbott, Toward a Richer Institutionalism for International Law and Policy, 1 J. INT'L L. \& INT'L REL. 9 (2005) (suggesting a joining of international relations theory and international law into a new unified legal discipline); Mathias Albert \& Rainer Schmalz-Bruns, Antinomien der Global Governance: Mehr Weltstaatlichkeit, weniger Demokratie? [Antimony of Global Governance: More World-Statehood, less Democracy], in DEMOKRATIE IN DER WELTGESELLSCHAFT [DEMOCRACIES IN THE WORLD COMMUNITY], supra note 21, at 57; Adrienne Héritier \& Dirk Lehmkuhl, The Shadow of Hierarchy and New Modes of Governance, 28 J. PUB. POL'Y 1 (2008) (evaluating the interplay of sectoral governance, or private regulation, and government policy-making); Christian Reus-Smit, The Constitutional Structure of International Society and the Nature of Fundamental Institutions, 51 INT'L ORG. 555 (1997) (analyzing the effects of issue-specific regulatory bodies on the structure of international regulation and policy-making). 
in what really should be a study of societal evolution. ${ }^{80}$ Through institutional analysis sociologists have contributed concepts such as institution, organization, territory, and space to depict the central dynamics of societal transformation today, ${ }^{81}$ tracing an evolution from territorially confined political communities to spatial "assemblages." 82 Such studies are further invigorated by fruitful tensions between concepts of spatially reconfigured spheres of community and power, ${ }^{83}$ and depictions of a functionally differentiated (world) society. ${ }^{84}$ This widening of the analytical lens invites studies on how overarching structures of society are reproduced through daily practice in remarkably diverse localities. ${ }^{85}$ Anthropologists engage in close studies of behaviors, attitudes, and actions on the ground, ${ }^{86}$ confronting human

80. See, e.g., Niklas Luhmann, Metamorphosen des Staates [Metamorphoses of the State], in GESELLSCHAFTSSTRUKTUR UND SEMANTIK: STUDIEN ZUR WISSENSSOZIOLOGIE DER Modernen Gesellschaft [Social Structure and Semantics: Studies on the SOCIOLOGY OF KNOWLEDGE BY THE MODERN COMMUNITY] 101 (1995) (Ger.); Niklas Luhmann, The World Society as a Social System, 8 INT'L J. GEN. SYS. 131 (1982) [hereinafter The World Society] (U.K.).

81. See, e.g., Saskia SASSen, Globalization and its Discontents (1998) (giving a broad overview of the author's perspective on the modern global economy); David Harvey, The Sociological and Geographical Imaginations, 18 INT'L J. POL. CULTURE \& SOC'Y 211 (2005) (discussing the role of geography and sociology in a modern conceptualization of the world); John W. Meyer et al., World Society and the Nation-State, 103 AM. J. Soc. 144 (1997) (demarcating the role of the nation-state in global interactions); Saskia Sassen, The State and Globalization, 5 INTERVENTIONS 241 (2003) (U.K.).

82. See, e.g., SASkia SASSen, TerRitory, Authority, Rights: From Medieval to GLOBAL ASSEMBLAGES (2006) (characterizing globalization as "denationalization" and describing the declining power of states in the face of rising transnational institutions).

83. See, e.g., Sassen, supra note 22; Boaventura de Sousa Santos, The World Social Forum and the Global Left, 36 POL. \& SoC'Y 247 (2008) (discussing the development of the World Social Forum and its contribution to the theory and practice of Left movements throughout the world).

84. See, e.g., Helmut WillKe, Global Governance (2006); The World Society, supra note 80 .

85. See generally Cynthia Enloe, Bananas, BeaChes AND BASEs: Making FEMINIST SENSE OF International Politics (1989); ISSA G. ShIVJI, Where IS UhURU? REFLECTIONS ON THE STRUGGLE FOR DEMOCRACY IN AFRICA 20-29 (Godwin R. Murunga ed., 2009); Cynthia Enloe, The Mundane Matters, 5 INT'L POL. Soc. 447 (2011); Xavier Guillaume, The International as an Everyday Practice, 5 INT'L POL. Soc. 446, 446 (2011).

86. See, e.g., Mariana VALVERdE, Everyday LaW on the StreEt: City GovernanCE IN AN AGE OF DIVERSITY (John M. Conley \& Lynn Mather eds., 2012) (undertaking a study of urban governance through a study of "everyday law" in the "law-and-society" tradition); Carol J. Greenhouse, Fieldwork on Law, 2 ANN. REv. L. \& Soc. SCI. 187 (2006) (considering multiple areas of scholarship across the disciplines of law and the social sciences); Mark B. Salter, Governmentalities of an Airport: Heterotopia and Confession, 1 INT'L POL. SOC. 49 (2007) (examining the balance between mobility and security involved in governing and policing a Canadian international airport). 
rights theory ${ }^{87}$ and taking the new technicalities of global governance such as indicators, performance yardsticks, and comparable governance instruments, 88 as empirical locations of new actor and norm creation, defying traditional assertions of sovereignty. It is through such concrete engagements with regulatory dynamics and power relations in complex societal settings that the abysses between northern and southern epistemologies may be overcome. ${ }^{89}$ Finally, history and geography have been contributing crucial insights into the dynamics and shapes of global governance constellations. Apart from the already alluded-to social history approaches in the tradition of E.P. Thompson, a recent theoretical and conceptual innovation is transnational history, ${ }^{90}$ which significantly expands the conceptual scope of historical analysis in a context already demarcated transnational by sociologists and legal scholars, ${ }^{91}$ but also poses grand questions for structures of power in the global realm. ${ }^{92}$ Another important strand of historical scholarship has emerged from among the group of scholars engaged in 'subaltern studies,' focusing on a Foucauldian analysis of the epistemic constructions of visions of social (Utopian) orders in concrete historical

87. See, e.g., Merry, supra note 5; Richard Ashby Wilson, Tyrannosaurus Lex: The Anthropology of Human Rights and Transnational Law, in THE PRACTICE OF HUMAN RightS: TRACKING LAW BETWEEN THE GLOBAL AND THE LOCAL 342 (Mark Goodale \& Sally Engle Merry eds., 2007) (complementing an emphasis on the discursive and social aspects of human rights by focusing on their legal character).

88. See SARFATY, supra note 49; Gerhard Anders, The Normativity of Numbers: World Bank and IMF Conditionality, 31 POLAR: POL. \& LEGAL ANTHROPOLOGY REV. 187 (2008); Andrea Ballestero S., Transparency Short-Circuited: Laughter and Numbers in Costa Rican Water Politics, 35 PoLAR: POL. \& LEGAL ANTHRopology REV. 223 (2012); Merry, supra note 23 (discussing the use of "indicators" as tools for assessing and promoting a variety of social justice and reform strategies around the world).

89. See generally JEAN COMAROFF \& JOHN L. COMAROFF, THEORY From THE SOUTH: OR, How EuRo-AmERICA IS Evolving TOWARD AFrICA (2012); Boaventura de Sousa Santos, Beyond Abyssal Thinking: From Global Lines to Ecologies of Knowledges, EUROZINE (June 29, 2007), http://www.eurozine.com/pdf/2007-06-29-santos-en.pdf.

90. See, e.g., Osterhammel \& PETERSSON, supra note 1; Sebastian Conrad, Globalization Effects: Mobility and Nation in Imperial Germany, 1880-1914, 3 J. GLOBAL HIST. 43 (2008) (discussing the effects of globalization on the trajectories of German nationalism in the nineteenth century); Jürgen Osterhammel, Transnationale Gesellschaftsgeschichte: Erweiterung oder Alternative? [Transnational Social History: Extension or Alternative?], 27 GESCHICHTE UND GESELLSCHAFT [HISTORY AND SOCIETY] 464 (2001) (Ger.).

91. See, e.g., JeSsup, supra note 11; ThE Transnational Studies Reader: INTERSECTIONS AND INNOVATIONS (Sanjeev Khagram \& Peggy Levitt eds., 2008).

92. See generally MARK MAZOWER, GOVERNING THE WORLD: THE RISE AND FALL OF AN IDEA, 1815 TO THE PRESENT (2012). 
and spatial settings. ${ }^{93}$ This line of research fruitfully complements the way in which global governance geographers have, since Montesquieu, studied social and economic dimensions, fruitfully adapting geographical categories to contribute a nuanced appreciation of cartography, mapping, and demarcation, ${ }^{94}$ with significant impact on sociological and legal research. 95

\section{E. Boundaries and Confinements: The Effects of Scale \& Jurisdiction}

The interdisciplinary approach proposed here draws on methodological work to identify analytical and regulatory challenges through the conceptualization of problem-driven research frameworks. ${ }^{96}$ Examples of emerging research frameworks that seek to respond to complex constellations in areas such as environmental or financial regulation include science and technology studies, sustainability governance, ${ }^{97}$ global transformations, ${ }^{98}$ transnational governance, ${ }^{99}$ and

93. Michael D. Gordin, Helen Tilley \& Gyan Prakash, Introduction: Utopia and Dystopia beyond Space and Time, in UTOPIA/DYSTOPIA. CONDITIONS OF HISTORICAL Possibility (Michael D. Gordin, Helen Tilley \& Gyan Prakash eds., 2010), at 4.

94. See, e.g., Harvey, supra note 81; Krugman, supra note 7 (reviewing the aspects of "new economic geography" as a theoretical construct and new genre contributing to the study of economics).

95. See Joel Bakan \& Nicholas Blomley, Spatial Categories, Legal Boundaries and the Judicial Mapping of the Worker, 24 ENV'T \& PLAN. 629 (1992); Richard T. Ford, Law's Territory (A History of Jurisdiction), $97 \mathrm{MICH}$. L. REV. 843 (1999) (arguing that territorial jurisdictions are new and surprising "technological developments" that produce political and social identities); Gerald Frug, A Legal History of Cities, in THE LEGAL GeOGRAPHIES READER 154 (Nicholas Blomley, David Delaney \& Richard T. Ford eds., 2001); Mariana Valverde, Jurisdiction and Scale: Legal 'Technicalities'as Resources for Theory, 18 Soc. \& LEGAL STUD. 139 (2009) (demonstrating that theoretical work on "scale" can benefit from studying legal mechanisms such as "jurisdiction").

96. See generally Philip Liste, The Politics of (Legal) Intertextuality, 4 INT'L PoL. Soc. 318 (2010) (applying "intertextuality" in an effort to consider law in its societal environment); Philip Liste, 'Public' International Law? Democracy and Discourses of Legal Reality, 42 NETH. Y.B. INT'L L. 177 (2011) (using discourses over the war in Iraq to demonstrate that governments can no longer define law in isolation from their societal environments) (Neth.).

97. See, e.g., Dena P. MacMynowski, Pausing at the Brink of Interdisciplinarity: Power and Knowledge at the Meeting of Social and Biophysical Science, 12 ECOLOGY \& Soc'Y (2007), http://ecologyandsociety.org/vol12/iss1/art20 (introducing a "Science and Technology Studies" perspective into environmental scientists' thinking about interdisciplinarity); Elinor Ostrom, Challenges and Growth: The Development of the Interdisciplinary Field of Institutional Analysis, 3 J. INSTITUTIONAL ECON. 239 (2007) (describing the recent intellectual challenges to traditional economics and political science disciplines and the development of an interdisciplinary institutional analysis) (U.K.). 
behavioral economics, which surfaced briefly, 100 and revitalized after the 2008 financial crisis. 101 Despite the respective breadth of these approaches, their contribution to theory on law's nature and function in the context of global governance has been limited. As argued above, a focus on the triad of norms, actors, and processes may allow us to more adequately theorize the emerging forms of law and regulatory governance in the context of a transdisciplinary, context-sensitive analysis of emerging transnational governance constellations. Methodologically, the approach proposed here is further inspired by the concepts of scale, jurisdiction, and mapping, influentially theorized by the legal sociologist Boaventura de Sousa Santos and the criminologist Mariana Valverde. While, within legal discourse, scale demarcates different levels of legal-political ordering (local, national, international, and global), jurisdiction functions as a mapping of normative and institutional reach, demarcating spheres of political/legal authority and competence. ${ }^{102}$ As such, the categories of scale and jurisdiction are deeply invested in the construction and the mapping of a space of and for law, with significant consequences for how claims and rights are recognized and administered. ${ }^{103}$

Scholars have long pointed to the political, constitutive effects of jurisdictional boundary setting, thus giving rise to critiques of how spaces are created for the formulation (or denial) and mobilization (or obstruction) of legal rights. ${ }^{104}$ After critical geographers took up the challenge of comparing the effects of mapping spaces and territories in

98. See generally THE GLOBAL TRANSFORMATIONS READER: AN INTRODUCTION TO THE GLOBALIZATION DEBATE, supra note 26 (collecting studies from a range of disciplines on the nature and historical significance of globalization).

99. See generally Regina Kreide, Transnational Governance and Human Rights: The Obligations of Private Actors in the Global Context, in Transnational STANDARDS OF Social ProteCtion 133 (Christian Joerges \& Poul F. Kjaer eds., 2008); Craig Scott \& Robert Wai, Transnational Governance of Corporate Conduct Through the Migration of Human Rights Norms: The Potential Contribution of Transnational 'Private' Litigation, in TRANSNATIONAL GOVERNANCE AND CONSTITUTIONALISM 287 (Christian Joerges et al. eds., 2004).

100. See generally John Maynard Keynes, The General Theory of EmPloyment, INTEREST, AND MONEY 147-64 (1935) (discussing the "state of long-term expectation" in investment).

101. See generally George A. AKerlof \& Robert J. ShILleR, ANimal SPIRITS: How Human Psychology Drives the ECONOMY, and Why It MatTers For Global CAPITALISM (2009); BEHAVIORAL LAW AND ECONOMICS (Cass R. Sunstein ed., 2000).

102. See Paul Schiff Berman, The Globalization of Jurisdiction, 151 U. PA. L. REV. 311 (2002).

103. See Ford, supra note 95 , at 852-54.

104. See Ford, supra note 94; Karen Knop, Ralf Michaels \& Annelise Riles, Transdisciplinary Conflict of Laws: Foreword, 71 LAW \& CONTEMP. PROBS. 1 (2008). 
both cartography and in law, ${ }^{105}$ legal sociologists and urban studies scholars have further scrutinized the connections between mapping, scaling, and jurisdictional allocation. The interim result of these endeavors is a rich and nuanced critique of the connection between scalar and jurisdictional boundary setting on the one hand and conceptualizations of political representation and legal regulation on the other. ${ }^{106}$ According to Santos, scale results in transposing one social element into several legal items. A locally positioned social conflict, for example a case about employment rights and workplace regulation (such as in Lochner), attains different significance depending on the level (scale) on which it is being addressed. For the parties on the ground, the conflict is concrete: legal positions, entitlements, and rights are concretely identified in the dispute, and, likewise, the context, history, and trajectory of the conflict can be identified. On the national level, however, the conflict becomes a substantively abstracted version of the concrete, detail-rich conflict as it occurred on the local level, resulting in a reconfirmation or adaptation of general legal principles. On a yet higher scale, the original conflict is assessed partly within a web of management/strategy decisions on the part of the multinational company, whose subsidiary is, or is associated with, one of the local parties. At the same time, the occurrence of the conflict on the ground is now seen on the national regulatory level to have indirect, if not direct, relevance for the understanding of the law governing cases such as that at hand. The law now at issue here is, in fact, a combination of widely diversified rules in, for example, corporate law, labor and employment law, the law governing industrial relations, constitutional law, and contract law. These norms are embedded in different regulatory areas of law, but are all considered part of the hard core of an official legal regulatory system. But, complementing these legal norms are numerous soft laws and codes, which emerge from regulatory activities of public-private actors on a transnational level. Norms governing corporate conduct with regard to employees (as well as other stakeholders and social or environmental concerns) originate as much from a (combination of) official hard law as from soft law emanating

105. See generally Nicholas K. Blomley \& Joel C. Bakan, Spacing Out: Towards a Critical Geography of Law, 30 OSGOODE HALL L.J. 661 (1992) (Can.).

106. See VALVERDE, supra note 40; Boaventura de Sousa Santos, Law: A Map of Misreading. Toward a Postmodern Conception of Law, 14 J.L. \& Soc'Y 279 (1987) [hereinafter A Map of Misreading]; Valverde, supra note 95 (demonstrating that theoretical work on "scale" can benefit from studying legal mechanisms such as "jurisdiction"); Boaventura de Sousa Santos, The Processes of Globalisation, EUROzINE (Aug. 22, 2002), http://www.eurozine.com/pdf/2002-08-22-santos-en.pdf (identifying the current state of globalization and discussing the unequal economic and political realities between the North and South). 
from a deeply heterarchical, transnational system, for example, human rights principles for multinational corporations developed by United Nations agencies, ${ }^{107}$ codes of conduct developed by international actors such as the International Labor Organization (ILO), the Organization of Economic Cooperation and Development (OECD), internationally active investment funds such as the California Public Employees Retirement System (CALPERS), or best practice guidelines disseminated by multinationals themselves.

The resulting challenge for lawyers is two-fold. One challenge is to understand the relations between the rules on every scale as interlegality, for example, to view law as resulting from an interaction of competing and complementing claims of validity on different levels. The second challenge is to recognize the dynamics between hard and soft law at the heart of each legal order, a distinction Santos captures by the distinction of center and periphery of law. For Santos, a legal system evolves, on the one hand, through conceptualizations, interpretative styles and techniques, and ideologies, which have formed at the core of a legal order due to institutionalized processes of rule creation and adjudication and are constantly being exported to the periphery, which is where they are applied in less formalized and institutionalized contexts. At the periphery, the application of such grounded, conceptualized rules is no longer straightforward due to the conflict between rules and local customs, practices, understandings, and routines of law now operating in a "twilight zone."108 Lawyers must develop a differentiated response to the fluid states of formalization and institutionalization in this zone. This necessitates a focus on this intersection of interlegality and legal pluralism, but seeks to push the methodological investigation further still. In terms of the disembeddedness of contexts of rights creation, implementation, and adjudication in a global context (an arena in which rights are ascribed to particular actors only with significant difficulty and with elusive effects in terms of realization and enforcement), the task is to

107. See generally David Weissbrodt \& Muria Kruger, Norms on the Responsibilities of Transnational Corporations and Other Business Enterprises with Regard to Human Rights, 97 AM. J. INT'L L. 901 (2003); Christiana Ochoa, The 2008 Ruggie Report: A Framework for Business and Human Rights (Ind. Univ. Sch. of Law-Bloomington, Legal Studies Research Paper Series, Research Paper No. 110, 2008), available at http://ssrn.com/abstract=1148428. See also U.N. Special Representative of the Secretary-General, Business and Human Rights: Further Steps Toward the Operationalization of the "Protect, Respect and Remedy" Framework, I 107, U.N. Doc. A/HRC/14/27 (Apr. 9, 2010), available at http://baseswiki.org/w/images/en/0/04/2010_Advance_Edited_Report.pdf.

108. See A Map of Misreading, supra note 106, at 292 (describing the periphery as a "twilight zone where the shadows of different legal orders converge"). 
adequately capture the structural dynamics which mark the interplay of norms, actors, and processes, in view of hopefully contributing to the development of legal doctrinal elements which are responsive to emerging, legal-political institutions, ${ }^{109}$ and to volatile rule-creation processes touching on core concerns of social regulation. ${ }^{110}$

A further emphasis in this approach concerns the question how the concept of legal pluralism ${ }^{111}$ can be expanded into a conceptual framework through which to address the different epistemologies that shape legal and political imaginations in the global collision of rationalities-beyond abyssal thinking. ${ }^{112}$ This step is vital to the proposal to bridge and bring into dialogue the sociological discourses on knowledge societies ${ }^{113}$ and the investigations into post-colonial consciousness and imagination ${ }^{114}$, including the critique of the economics and politics of post-colonial state sovereignty. ${ }^{115}$ While the former advance understandings of the far-reaching consequences of societal differentiation for conceptualizations of law, the role of the state and core distinctions such as public/private or state/society in and for the global North, ${ }^{116}$ the latter open up important vistas on emerging

109. See generally Santos, supra note 83.

110. See generally Philip Alston, Facing Up to the Complexities of the ILO's Core Labour Standards Agenda, 16 EUR. J. INT'L L. 467 (2005) (discussing the role of the International Labour Organization in defining core labor standards and the continued need to protect important substantive social rights in establishing those standards); Larry Catá Backer, Private Actors and Public Governance Beyond the State: The Multinational Corporation, the Financial Stability Board and the Global Governance Order, 17 IND. J. GLOBAL LEGAL STUD. 101 (2011) (discussing the coordination of private regulatory bodies and transnational public governance systems).

111. See generally H.W. Arthurs, Labour Law Without the State?, 46 U. TORONTO L.J. 1 (1996); John Griffiths, What is Legal Pluralism?, 24 J. LEGAL PLURALISM \& UNOFFICIAL L. 1 (1986) (U.K.).

112. Santos, supra note 89 , at 1.

113. See generally Helmut WILLKE, SMART GovernancE: Governing THE GLobaL KNOWLEDGE SOCIETY (2007); Nico Stehr, Knowledge Societies, in SOCIETY AND Knowledge: Contemporary Perspectives IN the Sociology of KNowledge and SCIENCE 299 (Nico Stehr \& Volker Meja eds., 2d rev. ed. 2005).

114. See generally ACHILle MBembe, ON THE Postcolony (2001); John L. Comaroff \& Jean Comaroff, Law and Disorder in the Postcolony: An Introduction, in LAW AND Disorder IN THE Postcolony 1 (Jean Comaroff \& John Comaroff eds., 2006). For a pertinent analysis of the tensions between 'traditional' and 'modern' conceptions of legality and how the state's perception and framing of 'relevant' aspects of societal order regularly missed the particulars of existing rules and ordering concepts, in particular as regarding the allocation and use of property, see JAMES C. SCOTT, SEEING LIKE A STATE (1998).

115. Comaroff \& Comaroff, supra, note 114, at 10.

116. See A. Claire Cutler, Artifice, Ideology and Paradox: The Public/Private Distinction in International Law, 4 REv. INT'L POL. ECON. 261 (1997) (examining the distinction between public and private international law); Fleur Johns, Performing Power: The Deal, Corporate Rule, and the Constitution of Global Legal Order, 34 J.L. \& Soc'Y 116 (2007) 
political-discursive cultures ${ }^{117}$ in the global South. Scholarship on the global South highlights evolving discourses that seek to resist universalizing modernization and development narratives originating in the colonial project and with significant continuities in post-colonial development and good governance agendas of international political and financial institutions. ${ }^{118}$ The North's stigmatizing framing of the South as savage and backward in contrast to the North's self-description as coherently ordered, ${ }^{119}$ provides an important pathway to a detailed assessment of the correlations between evolving narratives of sociolegal and political consciousness in terms of North/South. The previously alluded-to parallel readings will focus on these coevolutions of development and transformation narratives in order to capture the connections that are being established in theories of global governance between moments in time that are considered to have triggered a particular development and assessment. A closer inquiry into universalizing, Western assertions of key moments-e.g. the end of World War II, the establishment of the Bretton Woods institutions, the fall of the Berlin Wall, or September 11th and its aftermath ${ }^{120}$-lays bare the order-constituting effects such qualifications have on the conceptualization and consolidation of administered power relations. ${ }^{121}$

(discussing the nature of the legal work involved in executing transnational corporate dealings); Karl-Heinz Ladeur, Constitutionalism and the State of the 'Society of Networks': The Design of a New 'Control Project' for a Fragmented Legal System, 2 TRANSNAT'L LEGAL THEORY 463 (2011); Peer Zumbansen, Law After the Welfare State: Formalism, Functionalism and the Ironic Turn of Reflexive Law, 56 AM. J. CoMP. L. 769 (2008) (comparing the rise of social interventionist states in the United States and Germany to identify the state of law after the development of the welfare state).

117. See Annelise Riles, Anthropology, Human Rights, and Legal Knowledge: Culture in the Iron Cage, 108 AM. ANTHROPOLOGIST 52 (2006) (arguing that discursive engagement between anthropology and human rights is animated by the instrumentalism of legal knowledge).

118. See Sundhya Pahuja, Decolonising InTernational LaW: Development, ECONOMIC GROWTH AND THE POLITICS OF UNIVERSALITY (2011) (discussing the role of contemporary international law in combating global inequality and interventionist strategies using the rule of law to improve development in developing nations); Gathii, supra note 45 (tracing three broad modern approaches to "Third World" international ecoonomic governance); Sundhya Pahuja, Global Formations: IMF Conditionality and the South as Legal Subject, in CRITICAL BEINGS: LAW, NATION AND THE GLOBAL SuBJECT 161 (Peter Fitzpatrick \& Patricia Tuitt eds., 2004).

119. See Santos, supra note 89.

120. See generally Habermas, supra note 51 (discussing the aftermath of the September 11th attacks, including the Iraq War and the war against terrorism).

121. See, e.g., Events: ThE FORCE OF INTERNATIONAL LAW (Fleur Johns et al. eds., 2011) (analyzing international law through historical events that had an impact on its development). 
The parallel reading and assessment of national and transnational governance discourses will thus be structured by the employment of norms, actors, and processes on the one hand, and by a critical use of jurisdiction and scale on the other. Mariana Valverde's attention to jurisdiction and scale is of great value in this regard. Valverde argues that jurisdiction expresses law's governance of social facts and hereby effectively reduces the essential question of jurisdictions and levels of governance to a matter of competence (sovereignty). As a result, it tends to obstruct a scrutiny of what acclaim, benefit, and detriment attaches to how elements are governed. In disputes over institutional competence, the legal challenge is regularly directed at the level of jurisdiction, far less frequently at the how of governing a particular social constellation. ${ }^{122}$

\section{Translation Categories and The Grounding of Theory Through TRANSNATIONAL CASE STUdies}

A central contention in this paper has been that categories through which we may hope to capture the evolving normative and institutional infrastructure of transnational governance can no longer be developed from within one particular disciplinary framework-such as law, political science, or sociology. Instead, the categories contemplated here are more general than categories that are central to individual disciplines such as, for example, law. Categories at the core of legal

122. An illustration of this approach is, for example, the decision of the Supreme Court of Canada that concluded that Eskimos were to be treated by law as "Indians." See Re Eskimos, [1939] S.C.R. 104 (Can.). The court thereby created an obligation on the federal level to provide for them in cases of emergencies such as famines rather than forcing them to rely on charitable aid provided by provincial authorities. This case, seemingly beneficial for the Eskimos (Inuit), confined the challenge before the court to a question of jurisdiction, i.e., to an analysis of sovereignty and competence. What was not addressed in this context is the question of how Eskimos and other aboriginal groups were being, and ought to be, governed. Raising this more fundamental question, and going beyond the question of jurisdiction, would likely have allowed for a more encompassing deliberation on the policy foundations of rules pertaining to aboriginal rights in Canada. The shortcomings of such a legalistic approach, however satisfactory a particular result may appear at an assessment of the normative issues at hand at a given moment, is illustrated by emphasizing the fact that the legal treatment of aboriginal rights is, in the first place, the result of a legal construction demarcating valid (legal) and invalid (nonlegal) norms governing life in a given context. See generally JOHN BORROWS, RECOVERING CANADA: THE RESURGENCE OF INDIGENOUS LAW 111-37 (2002) (discussing "The Rule of Law, Aboriginal Peoples, and Colonialism" as it relates to Canada's title to land). Such distinctions and exclusions are at the heart of transnational governance case studies, highlighting the fact that law can be only one among several complementing approaches to generating knowledge about what is at stake in complex conflict and governance scenarios. 
theory and doctrine include: laws, legality, rule of law, separation of powers, and proportionality. These categories have attained their meaning within a particular reference framework, which-while evolving over time-continues to offer a context of meaning and embeddedness. The challenge which arises from the case constellations, which lawyers are confronted with in the context of transnational governance, is owed to the fact that this context cannot be taken for granted or referenced to in an attempt to situate and identify the parties to a conflict, their interests and stakes, and the avenues available to them to find judicial redress. The imported conceptions and understandings pertaining to the rule of law, rights, the existence and roles of a separation of powers system, or access to justice capacities will inevitably collide with the status such instruments and institutional configurations actually have in a local context. ${ }^{123}$ Legal anthropologists and legal sociologists conducting ethnographic studies on the nature of legal systems in numerous developing countries have been emphasizing the need to reconceptualize the concepts, frameworks, analytical toolkits, and instruments they meant to import into legal-economic-political cultures in light of the incompatibility of imported categories and locally existing structures of legal-social ordering. ${ }^{124}$ Likewise, law and development scholars have identified the pitfalls resulting from exporting domestic, predominantly Western and Northern conceptions of law and the legal system into contexts that are marked by a different legal tradition. ${ }^{25}$ Historians and anthropologists have famously complemented these accounts by introducing the theory of invented traditions, which highlights the degree to which numerous societal patterns, ordering structures, institutions, and processes identified as traditional must, in fact, be seen as constructions-as invented traditions-through acts of labelling and assigning, rather

123. See James C. ScotT, Seeing Like A STATE (1998), in particular Part 1 State Projects of Legibility and Simplification.

124. See, e.g., Francis G. SNYder, Capitalism and Legal Change: AN African TRANSFORMATION 1-22 (1981).

125. See Katharina Pistor \& Daniel Berkowitz, Of Legal Transplants, Legal Irritants, and Economic Development, in CORPORATE GovernanCE AND CAPITAL FLOWS IN A GLOBAL ECONOMY 347 (Peter K. Cornelius \& Bruce Kogut eds., 2003); Katharina Pistor, The Standardization of Law and Its Effect on Developing Economies, 50 AM. J. CoMP. L. 97 (2002) (suggesting that attempting to develop an "optimal" set of legal rules harmonizing law in different global markets fails to recognize the benefit of change, innovation, and adaptation of different institutions and organizations in a competitive environment); David M. Trubek \& Marc Galanter, Scholars in Self-Estrangement: Some Reflections on the Crisis in Law and Development Studies in the United States, 1974 WIS. L. REV. 1062 (1974) (discussing the relationship between the legal systems and social, economic, and political changes in developing countries and the inability of scholars adequately to define the nature of their work in these areas of law and development). 
than from an adequate excavation of actually existing and evolving societal patterns. ${ }^{126}$

These findings prompt lawyers involved in not only legal aid and law reform projects in developing countries, but also comparative lawyers to take a second, serious look at their packed conceptual, analytical, and theoretical luggage with which they embark on projects and comparisons. While the need to develop a comparative law concept in a direct exchange with the object of comparison has long been noted, ${ }^{127}$ the challenge for scholars and practitioners engaged in legal transplants and law and development projects can now be described in a further differentiated manner. To the degree that the political and cultural hegemony critique that was launched against the comparative project $^{128}$ has by now become quite accepted, ${ }^{129}$ the significance of anthropological insights into the materiality of societal patterns and existing modes of property transfer, conflict resolution, and rights and claims recognition and administration, ${ }^{130}$ has important consequences for law and development and comparative law. The challenge for these enterprises to understand foreign legal cultures can today be seen in an even brighter light, illuminating the need to develop an even more responsive and learning approach to the study of societal ordering

126. Eric Hobsbawm, Introduction: Inventing Traditions, in THE INVENTION OF TRADITION 1, 1-2 (Eric Hobsbawm \& Terence Ranger eds., 1983) (“Invented tradition' is taken to mean a set of practices, normally governed by overtly or tacitly accepted rules and of a ritual or symbolic nature, which seek to inculcate certain values and norms of behaviour by repetition, which automatically implies continuity with the past. In fact, where possible, they normally attempt to establish continuity with a suitable historic past .... However, insofar as there is such reference to a historic past, the peculiarity of 'invented' traditions is that the continuity with it is largely factitious. In short, they are responses to novel situations which take the form of reference to old situations, or which establish their own past by quasi-obligatory repetition."). See also ROBERT BOROFSKY, MAKING HISTORY: PUKAPUKAN AND ANTHROPOLOGICAL CONSTRUCTIONS OF KNOWLEDGE (1987) (comparing two distinct ways of "making history" or "constructing knowledge about the past").

127. See H. Patrick Glenn, Legal Tradition of the World: Sustainable Diversity IN LAW (2d ed. 2004); Jonathan Hill, Comparative Law, Law Reform and Legal Theory, 9 OXFORD J. LEGAL STUD. 101 (1989).

128. See Hill, supra note 127.

129. See Comparative law as Transnational law: a Decade of the German law JoURnal (Russell A. Miller \& Peer C. Zumbansen eds., 2011); EsIN ÖRÜcÜ, THE ENIGMA OF COMPARATIVE laW: VARIATIONS ON A THEME FOR THE TWENTY-FIRST CENTURY (2004); Ralf Michaels, Im Westen nichts Neues? [Nothing New in the West?], 66 RABEL ZEITSCHRIFT FÜR AUSLÄNDISCHES UND INTERNATIONALES PRIVATRECHT (RABELS J. COMP. INT'L PRIVATE L.] 97 (2003) (Ger.) (discussing the status of comparative law, how it has been important in the past, and suggesting that its application to new issues might be necessary to prevent comparative law from becoming irrelevant).

130. See SNYDER, supra note 124. 
mechanisms and foreign legal systems. ${ }^{131}$ In light of the just described coalescing of different disciplinary contributions to the study of legal cultures it appears appropriate to seek for an analytical toolkit to contain instruments and categories, which are adequate to the emerging interdisciplinary conceptual framework. Such instruments will be crucial in the study and the understanding of emerging transnational governance constellations, involving local and foreign, transnational actors, norms, and processes. As a response to these constellations, the suggestion made here is to conceptualize actors, norms, and processes as translation categories. Their function would not consist in dismissing the conceptual heritage of the past through a purportedly new terminological orconceptual architecture. Rather, these categoriesnorms, actors, and processes-are meant to both trace the connections and identify the gaps between existing and emerging conceptualizations of societal change and regulatory models. These categories allow us to enrich and build on existing disciplinary narratives: Norms allows us to study, from a historical-comparative perspective, the genealogies and contestations relating to law, rules, orders, legal pluralism, custom, and social norms. Actors illuminate the trajectories and conflicts relating to state, society, community, and organization. An emphasis, lastly, on processes is similar, arguably, to the rich semantic and political history of contract. ${ }^{132}$ With the capacity to transcend disciplines, processes illuminate the dynamics of institutional evolution in the complex interplay of norms and actors today, reflecting engagement, interaction, contestation, resistance, opposition, and voice. In short, through a focus on norms, actors, and processes we seek to turn away from the exhaustion of hybrid and singular disciplinary accounts toward a comprehensive and interdisciplinary research agenda. The promise of employing these categories lies in their generality and permissiveness to take on board and make visible actually existing patterns of societal-legal ordering. The distinct difference to the current state of critically engaging with the challenges of comparative law and legal

131. See Günter Frankenberg, Critical Comparisons: Re-thinking Comparative Law, 26 HARV. INT'L L.J. 411 (1985).

132. See generally P.S. ATIYAH, THE RISE AND FALL OF FREEDOM OF CONTRACT (1979); Charles Fried, Contract as Promise (1981); WolfGang Kersting: Die Politische

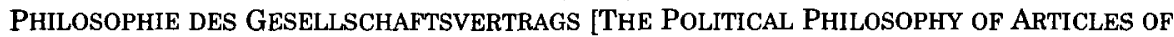
Association] (1994) (Ger.); Roger Brownsword, Contract Law, Co-operation, and Good Faith: The Movement from Static to Dynamic Market-Individualism, in CoNTRACTS, CO-OPERATION, AND COMPETITION 255 (Simon Deakin \& Jonathan Michie eds., 1997); Morris R. Cohen, The Basis of Contract, 46 HARV. L. REV. 553 (1933); Simon Deakin et al., Contract Law, Trust Relations, and Incentives for Co-operation: A Comparative Study, in CONTRACTS, Co-OPERATION, AND COMPETITION, supra at 105. 
transplants ${ }^{133}$ lies in the introduction of categories that do not claim to carry any preexisting conceptions of the meaning, scope, and function of law, the public or private nature of rule-generating institutions, or the legality of the rule-generating and rule-implementing process. As such, norms, actors, and processes as a triadic concept would be able to capture these dimensions ('law state, and rule of law') as having evolved within the Western/Northern legal culture, but the concept suggested here would not be shaped or, more importantly, predetermined by these dimensions and experiences. Instead, norms, actors, and processes would work as excavation instruments to bring to light those norms, actors, institutions, and processes that actually constitute a particular legal order.

Relying on this toolkit, the approach sketched here seeks to contribute to a theory and practice of interdisciplinary research to operationalize these translation categories-norms, actors, and processes-in complex transnational governance constellations through the use of case studies. Different than strictly legal cases, the case studies proposed here involve ethnographic analysis of governance practices in politically and normatively sensitive areas such as human rights conflicts in the extraction industry, natural resource governance, indigenous rights, religious identity claims in secular societies, contestation between retroactive and transitional justice in post-conflict settings, the concept of the rule of law in international development and state building, transnational private regulatory governance, financial regulation, and the crucial role of nonstate actors. While transnational governance constellations increasingly attract a multidisciplinary approach to address legality, legitimacy, and enforcement concerns, the goal is to scrutinize the ways in which law has not satisfactorily taken up this interdisciplinary development. A legal theory of global governance should not just borrow from other disciplines, but contribute to an interdisciplinary governance theory. In that vein, an examination of how the traditional legal framing of a case selects from facts considered relevant or irrelevant and ends up too often de-contextualizing the legal case from the underlying complex societal conflict and regulatory constellation is necessary.134 By focusing on

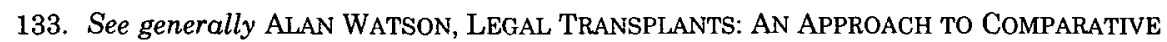
LAW (1974); Pierre Legrand, Comparative Legal Studies and the Matter of Authenticity (Univ. of San Diego Sch. of Law Legal Studies Research Paper No. 08-071, 2008), available $a t$ http://www.sssup.it/UploadDocs/3331_SSRN_ID1259920_code254274.pdf.

134. For an illustration of how a particular epistemic (modernist-enlightenment) bias has perpetrated the dominance of Western concepts of economic and technological progress over different visions of the status and use of nature and natural resources, see, Usha Natarajan, TWAIL and the Environment: The State of Nature, The Nature of the State, and the Arab Spring, 14 OR. L. REV. 177 (2012), at 192. See also, LINDA TUHIWAI 
norms, actors, and processes, these constellations might be grasped through a fresh, genuinely interdisciplinary lens, making visible manifold competing interests, accounts of power, abilities, and barriers to the justice system.

The transnational governance case studies envisioned here, including but not limited to conflicts arising, for example, from multinationals' operations including mining or large scale infrastructure construction in developing countries, ${ }^{135}$ function as laboratories to study intersecting governance narratives, unfolding in often difficult, power-fraught interactions between international organizations, private actors, and local interest groups. Such case studies will be central to the development of context-sensitive and interdisciplinary approaches to uncover the different dimensions of particular problem constellations or regulatory challenges, for example in economic and ecological governance or human rights activism. ${ }^{136}$ Because many of the concepts used in the case studies are not new but have a significant semantic heritage, 137 close attention to historical and contextual detail is a crucial methodological element of the approach suggested here. While this emphasis on an attention paid to local and historical detail is inspired by the social history approach, particularly as developed by E.P. Thompson, ${ }^{138}$ and also to the scholarship on

Smith, Decolonizing Methodologies. Research and Indigenous Peoples (2nd ed., 2012), 61-64.

135. See, e.g., Stephen J. Kobrin, Private Political Authority and Public Responsibility: Transnational Politics, Transnational Firms, and Human Rights, 19 Bus. ETHICs Q. 349 (2009); Richard Meeran, Tort Litigation against Multinational Corporations for Violations of Human Rights: An Overview of the Position Outside the United States, 3 CITY U. H.K. L. REV. 1 (2011).

136. See generally Christiana Ochoa, The Relationship of Participatory Democracy to Participatory Law Formation, 15 IND. J. GLOBAL LEGAL STUD. 5 (2008); Cesar Rodriguez-Garavito, Ethnicity.gov: Global Governance, Indigenous Peoples, and the Right to Priorm Consultation in Social Minefields, 18 IND. J. GLOBAL LEGAL STUD. 263 (2011); Elinor Ostrom, A Polycentric Approach for Coping with Climate Change (The World Bank Dev. Econ. Office of the Senior Vice President \& Chief Economist, Policy Research Working Paper No. 5095, 2009), available at http://wwwwds.worldbank.org/external/default/ WDSContentServer/IW3P/IB/2009/10/26/000158349_20091026142624/Rendered/PDF/WP S5095.pdf.

137. See Maurice Halbwachs, On Collective Memory (Lewis A. Coser ed. \& trans., Univ. of Chi. Press 1992) (1941); Yosef HaYIM YeRUShaLmi, ZaKHOR: JEWISH HISTORY AND JEWISH MEMORY (1982).

138. See EdWard Palmer Thompson, The Making of the English Working Class (1963); Craig Calhoun, E.P. Thompson and the Discipline of Historical Context, 61 Soc. RES. 223 (1994); Robert W. Gordon, Tribute: E.P. Thompson's Legacies, 82 GEO L.J. 2005 (1994); E.P. Thompson, The Moral Economy of the English Crowd in the Eighteenth Century, 50 PAST \& PRESENT 76 (1971). 
invented traditions, ${ }^{139}$ it connects it with the interest of anthropological ethnographic research in the actual operations of economic, legal, and political actors. ${ }^{140}$ Such an approach will allow for a scrutiny of competing assertions of legality/illegality, law/nonlaw, and hard/soft law concepts in order to adequately capture the process dynamics which unfold between different local and transnational actors and norms.

A central contention of this paper has been that the real potential of the identified translation categories-norms, actors, and processes-lies in the links that they create between known and new cases. In other words, it is crucial to create a connection and dialogue between cases that lawyers coming out of a particular legal tradition have experienced, registered, and eventually canonized as hard cases, and as landmark or milestone moments in the development of the law on the one hand and the struggles to capture the case behind complex social, economic, cultural, and religious facts found in a transnational governance constellation, on the other. This dialogue is crucial if one is to avoid the importing of pre-conceptions from a known legal order into a new, foreign context of legal-regulatory conflict. These patterns of concept-import can be made visible by revisiting important cases from one's legal order in an attempt to extract, in a first step, the lessons that have so far been drawn from a landmark case in order to, in a second step, revisit these lessons and their adequacy for an adequate understanding of a conflict and collision of claims and interests in a new transnational context. To illustrate this bridge building between landmark cases from one legal culture to another and the challenges to identify, construct, and address an emerging case in a transnational governance context is the task of the following, concluding section of this essay.

\section{What's in a CASE? Disembedding Problem Solving: LochneR aS CASE IN POINT}

The attempt made in this paper to capture the complexity of emerging transnational governance constellations cannot occur in a vacuum. Instead, the central contention here is that there are intriguing

139. See generally THE INVENTION OF TRADITION, supra note 126 (arguing that many traditions that appear or claim to be old are often quite recent in origin and sometimes invented).

140. See generally JoHn L. COMARofF \& JEAN COMAROFF, ETHNICITY, Inc.: THE ZULU KINGDOM AWAITS YOU (2009); KAREN Ho, LIQUIDATED: AN ETHNOGRAPHY OF WALL STREET (2009); RILES, supra note 25; SARFATY, supra note 49; Comaroff \& Comaroff, supra note 114 . 
ways in which particular cases-seminal or canonical decisions ${ }^{141}$-have shaped and continue to influence our assertions of what lies at the core of newly emerging transnational cases that we are confronted with today. It is in that vein, that the engagement with such new cases but, more importantly, case studies of conflict constellations, will regularly unfold against the background of well 'known,' locally situated, but sometimes globalized case law, ${ }^{142}$ considered as having given rise to a legacy, even if the reasons for this status remain a matter of dispute. ${ }^{143}$ Such instances of judicial lawmaking are received and canonized as famous and as hard cases, ${ }^{144}$ having become, over time, contextualized in certain national legal traditions. Cases demarcating the boundaries between the state and the market, between assertions of political 'interventionism' on the one hand, and 'private ordering,' on the other, can be seen as having had played a significant role in the evolution of the Western legal imagination. ${ }^{145}$ This background has the effect, that by the time lawyers are demarcating the boundaries between freedom of contract and state interventionism, between public and private spheres of authority, or between judicial 'activism' and state action in a transnational context, it does not necessarily become obvious to what degree their perceptions of the existence as well as of the merit of such distinctions have been shaped by cases from their national legal canon. The question that is usually not asked in those circumstances is whether and to what degree this nationally informed conceptual framework $^{146}$ is adequate or can even be helpful in identifying the stakes in problem and conflict constellations in a transnational setting.

141. Jack M. Balkin, "Wrong The Day It Was Decided": Lochner and Constitutional Historicism, 85 B.U. L. REV. 677, 681 (2005) ("Canonical cases and materials are a terrain on which people fight battles about constitutional theory. Theorists who wish to be taken seriously in the relevant interpretive community feel that they must explain or incorporate these canonical cases or materials into their work if their theories are to be accepted; conversely, scholars find competing theories wanting to the extent that they do not offer satisfactory accounts of these canonical materials. Canonical cases are protean-they can stand for (or be made to stand for) many different things to different theorists, and that is what makes them so useful for the work of theory.").

142. See, e.g., Sujit Choudhry, The Lochner Era and Comparative Constitutionalism (Univ. of Toronto Faculty of Law, Pub. Law \& Legal Theory Research Paper No. 02.22, 2002), available at http://ssrn.com/abstract_id=363220.

143. See, e.g., Howard Gillman, De-Lochnerizing Lochner, 85 B.U. L. REV. 859 (2005).

144. The reference is, of course, to Ronald Dworkin, Hard Cases, 88 HARV. L. REV. 1057 (1975).

145. See, e.g., Morton J. Horwitz, The Transformation of AMERICAN LaW, 1870-1960: THE CRISIS OF LEGAL ORTHODOXY 33-64 (1992).

146. For an illustration, see Richard A. Posner, Creating a Legal Framework for Economic Development, 13 WORLD BANK RES. OBSERVER 1 (1998). 
As suggested in the title to this paper, the U.S. Supreme Court's 1905 decision in Lochner $v$. New York warrants an analysis of its domestic embeddedness in well-established discursive practices such as state 'intervention' versus market 'freedom' and in the context of institutional anchor points such as a separation of powers matrix that would allocate distinct competences to different branches of government while positing this arrangement against the background of an available constitutional text and an established interpretive constitutional practice. Meanwhile, the disembeddedness of a case such as Lochner unfolds in its problematic transposition into the context of transnational governance, which is marked by an extreme heterarchy of discursive positions and political stakes, by the absence of a fungible separation of powers framework and the, for now, elusive concept of a 'global' constitution. Seen through this lens, Lochner is-domestically-a canonical landmark case with a tremendous influence on the development of dominant conceptions and, polemics regarding the legal governance of market relations, precisely because the lines drawn by the majority opinion and at least one of the two dissenting justices (Oliver Wendell Holmes, Jr.) were so obviously attributable to accessible, opposed political stances, not to mention the differences between Peckham's and Holmes' theoretical standpoints. ${ }^{147}$ As such, a decision such as Lochner continues to have an immense impact on the evolving approaches to the identification of interests and stakes in a distinct legal imagination that has been resonating in Western legal theory and in the judicial politics of market governance. ${ }^{148}$ It is within that imagination where the choice between different modes of market governance is identified as a politically neutral, objective task. ${ }^{149}$ At the same time, Lochner's problematique of a state versus market juxtaposition casts a powerful spell over transnational market governance debate, when employing a predominantly nation-state centric perspective in the design of regulatory instruments. ${ }^{150}$

147. See Duncan Kennedy, Toward an Historical Understanding of Legal Consciousness: The Case of Classical Legal Thought in America, 1850-1940, 3 RES. L. \& SOC'Y 3 (1980), 9 14.

148. 198 U.S. 45 (1905).

149. Kennedy, supra note 147 , at 12 ("The notion is that of an objective task of drawing lines or categorizing actions as though they were objects to be located in the spatial map of spheres of power. This task constitutes itself a "power" to be exercised within and only within a limited sphere.").

150. Stephen K. Aikins, Global Financial Crisis and Government Intervention: A Case for Effective Regulatory Governance, 10 INT'L PUB. MGT. REV. 23 (2009) (observing that [national] "governments and their regulatory authorities need to put in place a proactive regulatory framework and institutional safefguards to guard against regulatory capture arbitrage and forbearance in order to control financial market excesses."). 
The suggestion here is to not only acknowledge the disembeddedness of Lochner in a transnational context, both regarding its lessons for global market regulation as well as for socio-economic conflicts arising out of multinational companies' much contested operation in developing countries, but to carve out the productive differences between a domestically embedded case and the particular qualities of comparable conflict scenarios in a transnational context. Thus, using a case such as Lochner as a laboratory in which to study the collision of different societal interests, claims to entitlements and rights on the one hand and the law's approach to resolving such complex conflicts on the other, will help us see how emerging transnational governance cases echo a number of Lochner's stakes while, at the same time, illustrating how the Lochnerian analytical framework might fall short of fully capturing the multi-layered dimensions and stakes at the heart of transnational governance conflicts. The reason for this shortcoming can be found in the fact that an analysis that seeks to develop analytical categories to understand transnational economic governance scenarios from a case such as Lochner is likely too focused on allegedly wellknown and understood interests and entitlements within a particular conceptualization of markets, states, and the law. In response, the purpose of a juxtaposition of landmark cases and their legacies with case studies of transnational socio-economic conflict constellations, for example, in developing countries, is to question to what degree our sensitivity to law's pitfalls, blindsides, and exclusionary dynamics, as studied through landmark cases such as Lochner, can and should continue to guide us in the unpacking of hard cases in transnational governance today.

In other words, what are the lessons to be drawn from an American case from 1905, which involved a state law setting a maximum number of working hours in bakeries? While both protagonists and issues at the heart of Lochner have long been seminal to debates over the boundaries between the state and free markets, ${ }^{151}$ we have to ask how helpful the particular framing of the problems identified in Lochner can be for an understanding of what is at stake, for example, in conflicts between multinational enterprises, their employees and the local communities in the countries of operation today. ${ }^{152}$ Similarly, we must ask how a

151. See Paul Kens, Lochner v. New York: Tradition or Change in Constitutional Law?, 1 N.Y.U. J. L. \& LIBERTY 404 (2005); David A. Strauss, Why Was Lochner Wrong?, 70 U. CHI. L. REV. 373 (2003). For a comprehensive discussion from the perspective of comparative constitutional law, see Choudhry, supra note 142.

152. For a highly informative and critical analysis of such conflicts, see DAVID Szablowski, Transnational Law aNd Local Struggles. Mining, Communities and 
problem awareness that was schooled along the confrontation lines between an allegedly private property (business, factory, or plant) owner or operator and a private employee, as was in the center of Lochner, may guide us in the identification of interests, vulnerabilities, and entitlements in circumstances, where already the allegedly private status of the business enterprise in its relation to the host government, the local authorities, and, oftentimes, the mixed, public-private constituencies of competing social groups (activists, militia, and social movements) are contested. ${ }^{153}$

Today, as we revisit this decision's multilayered legacy as a judicial endorsement of an allegedly unchallenged political-economic theory of freedom of contract, ${ }^{154}$ as a continuation of or a break with history, ${ }^{155}$ or as a bold act of ideologically driven judicial activism, ${ }^{156}$ we are facing a dilemma: to whom may we today compare the factory owner opposing the state legislator? In the current global environment of manifold stand-offs between winners and losers of globalization, ${ }^{157}$ whose interests are at stake in such litigations? How are we to identify and legally qualify, for example, the different interests around large-scale infrastructure, ${ }^{158}$ or extraction projects, ${ }^{159}$ in developing countries or in precarious political and economic settings? The urgency of such lines of questionings underscores the need for a methodological approach that ties current investigations into the nature of legal/nonlegal transnational governance into continuing developments of local, but increasingly transnational, regulatory cultures.

THE WORLD BANK (2007) (with a particular focus on Peru). See also LAYNA MOSLEY, LABOR RIGHTS AND MULTINATIONAL PRODUCTION 210-36 (2011) (with a focus on Costa Rica).

153. See, e.g., SzABLOWSKI, supra note 152; Rodriguez-Garavito, supra note 136.

154. See Strauss, supra note 151.

155. See Kens, supra note 151.

156. See Cass R. Sunstein, Lochner's Legacy, 87 CoLUM. L. REV. 873 (1987). But see David E. Bernstein, Lochner's Legacy's Legacy (George Mason Univ. Sch. of Law, Law \& Econ. Working Paper Series, Working Paper No. 03-15, 2003), available at http://papers.ssrn.com/sol3/papers.cfm?abstract_id=394861. For a blog entry discussing this scholarly dispute, see Damon W. Root, Lochner and Liberty: Dissecting the Supreme Court Case That Unites the New Regulatory Czar and His Conservative Critics, REASON.COM (Sept. 18, 2009), http://reason.com/archives/2009/09/18/lochner-and-liberty. See Gillman, supra note 143 , at 860-61, for an account of how little attention Lochner actually received at the time of its release.

157. See Jeffrey G. Williamson, Winners and Losers over Two Centuries of Globalization (Nat'1 Bureau of Econ. Research, Working Paper No. 9161, 2002), available at http://www.nber.org/papers/w9161.

158. See, e.g., Sarah C. Aird, China's Three Gorges: The Impact of Dam Construction on Emerging Human Rights, 8 HUM. RTS. BRIEF 24 (2001).

159. See, for example, the tort litigation concerning human rights violations in Guerrero v. Monterrico Metals Plc, [2010] EWHC (QB) 3228 (Eng.), available at http://www.bailii.org/ew/cases/EWHC/QB/2010/3228.html. 
The acknowledgement of Lochner's disembeddedness and the proposal to recontextualize its lessons and impact in a transnational context is based on a reconsideration of what has made this case seminal in an attempt to unpack a different kind of lesson to be drawn from such a landmark case for our conceptualization of transnational legal cases today. I want to suggest, in contrast to the canonized opposition between Rufus Peckham's majority opinion and Oliver Wendell Holmes, Jr.'s famous dissent, ${ }^{160}$ that we ought to direct our attention to another part of the judgment. The question ought to be: What might we discover about Lochner if we attend to the dissent written by Justice Harlan, rather than rehearsing current readings of Lochner as being emblematic of the contestation between state regulation and the free market?161 The reason for this reorientation follows from the epistemological challenges arising out of complex and multilayered transnational governance constellations that are marked by a significant degree of uncertainty and volatility as regards public and private authority, the parties' access to the justice system, legal representation, and due process as well as far-reaching challenges regarding the voice of many substantively invested interest carriers. With these in mind, Harlan's dissent appears in a particularly bright light in the way it outlines the future contours of a process of judicial review unfolding in a fast modernizing, complex soon-to-become risk society, where it has become common place to scrutinize judicial dependency on and engagement with expert opinion, altogether unfolding in an always precarious and unstable separation-of-powers architecture. ${ }^{162}$ This is true even if Harlan himself remains caught in the state-society juxtaposition that informs Peckham's majority opinion. ${ }^{163}$ It is this emphasis on the relevance of knowledge as it generated through a process-driven and competence-conscious undertaking that Harlan highlights and that bears particular promise for our current efforts in getting the facts right in the context of complex transnational governance constellations.

160. Gerald Leonard, Holmes on the Lochner Court, 85 B.U. L. REV. 1001, 1003 (2005) ("Holmes's Lochner dissent is probably more famous than any of the other opinions in the case, and some of the individual aphorisms in the case are probably even more famous than the dissent as a whole.")

161. Balkin, supra note 141, at 685 ("Following the struggle over the New Deal and the ascendancy of the Roosevelt Court, Lochner symbolized the constitutional regime that had just been overthrown.").

162. See, e.g., CAROL HaRlow \& RichaRd RAWLINGS, LAW AND ADMINISTRATION 106-13 (3d ed. 2009) (discussing theories of judicial review with respect to separation of powers). See also JAMES M. LANDIS, THE ADMINISTRATIVE PROCESS 123-55 (1938).

163. Kennedy, supra note 147 , at 12-13. 
Before we can make this leap, however, we need to, at least briefly, review what Harlan wrote in his dissent. Harlan's dissenting opinion presented a careful review of the state legislature's process by which it had crafted the statute in question-the 1895 New York Bakeshop Act. ${ }^{164}$ Harlan scrutinized, but did not second-guess the legislature's efforts to draw on a wide range of scientific evidence and expert opinion, eventually coming to a number of conclusions that prompted him to dissent. The first conclusion, upon reviewing previous case law was that it was "firmly established that what is called the liberty of contract may, within certain limits, be subjected to regulations designed and calculated to promote the general welfare or to guard the public health, the public morals or the public safety." 165 Upon reviewing academic and professional sources outlining possible dangers arising out of working conditions central to the case before the court, Harlan concluded:

There are many reasons of a weighty, substantial character, based upon the experience of mankind, in support of the theory that, all things considered, more than ten hours' steady work each day, from week to week, in a bakery or confectionery establishment, may endanger the health and shorten the lives of the workmen, thereby diminishing their physical and mental capacity to serve the state and to provide for those dependent upon them. If such reasons exist that ought to be the end of this case, for the state is not amenable to the judiciary, in respect of its legislative enactments, unless such enactments are plainly, palpably, beyond all question, inconsistent with the Constitution of the United States. ${ }^{166}$

Against this background, the argument being put forward here is that a legal theory of transnational governance needs to be sensitive to its own ignorance both as regards the architecture-institutionally and normatively - that is governing a case in a transnational setting and as regards the adequate ways to determine relevant information on the ground. In other words, in settings where societal conflicts involve a complex array of public, private, and mixed actors, precarious and unstable rule of law processes, vulnerable interests and insufficient

164. The statute's text is available at http://www.regulationonline.net/chapters/regch $1 /$ ny-bakeshop/.

165. Lochner v. New York, 198 U.S. 45, 67 (1905) (Harlan, J., dissenting).

166. Id. at $72-73$. 
capacity of voice, ${ }^{167}$ the distinction between legally relevant and irrelevant facts becomes one of crucial significance. It is in this light that the proposal made here suggests a relaxation of our usually applied categories to describe legal processes, institutions, rights, and laws and, instead, to employ categories that might assist in picking up on the institutional and normative dimensions governing a complex conflict constellation. The idea is to engage with norms, actors, and processes in the construction of a case in order to show how legal knowledge emanates and differs from competing accounts of permissible versus illegal conduct and legitimate versus illegitimate use of power and authority. Approaching such constellations through the proposed framework of norms, actors, and processes goes beyond the well-known juxtaposition of the majority opinion's embrace of a free market ideology in Lochner and Holmes's dissenting refutation of legal formalism. The norms, actors, and processes approach would, instead, inter alia, pay more attention to Justice Harlan's dissent that dwelt on the legislature's scientific expertise in conceptualizing workplace regulation and the need for the judiciary to endorse the allocated regulatory competences in a separation of powers system. Today, an emphasis on the precarious nature of knowledge and its crucial role in shaping what we identify as the "problem" in response to which regulatory responses are being crafted, prompts us to problematize and understand the context in which contested rights can be and are being articulated and legalized. This close attention to otherwise invisible or neglected interests has been emphasized by anthropologists and law and society scholars alike, and is today an urgent concern in global South scholarship and activism. ${ }^{168}$ In search of a legal theory of transnational governance, we need to assess the differences between the nature, quality, and form of the knowledge that Harlan referred to and the knowledge that informs governance decisions in today's highly diversified and contested glohal context. ${ }^{169}$ In other words, the task consists, for example, of emphasizing the nature and evolution of epistemology and knowledge in the formation of national and emerging

167. See generally Rodriguez-Garavito, supra note 136.

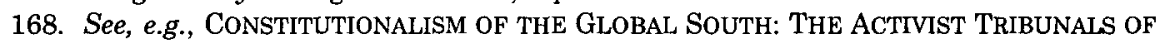
INDIA, SOUTH AFRICA, AND COLOMBIA (Daniel Bonilla Maldonado ed., 2013); Laura Nader, Epilogue: The Words We Use: Justice, Human Rights, and the Sense of Injustice, in MIRRORS OF JUSTICE: LAW AND POWER IN THE POST-COLD WAR ERA 316 (Kamari Maxine Clarke \& Mark Goodale eds., 2010).

169. See generally Boaventura de Sousa Santos, TOWARD a NEW Legal Common SENSE (2d ed. 2002); Bruno Latour, From Realpolitik to Dingpolitik or How to Make Things Public, in Making ThIngs PUbliC: ATMOSPheres of DeMocracy 14 (Bruno Latour \& Peter Weibel eds., 2005). 
global regulatory constellations. ${ }^{170}$ At the same time, ongoing legal proceedings that investigate decades-long disputes over the impact of multinationals' operations in colonial and post-colonial settings on employees but also much wider circles of stakeholders and communities, strongly point to the need to strengthen the knowledge basis on which legal allegations are rendered.171 In cases such as those involving the operation of multinational tire companies in countries, ${ }^{172}$ where generations of employees and community stakeholders have been pulled into the ambiguous grasp of a corporate actor that has long ceased to be a mere private business enterprise, it would seem pertinent to establish a thoroughly researched record to capture the historically evolved, particular qualities of the situation at hand. ${ }^{173}$

Perhaps the most pressing examples in that regard, multinational mining operations have for a long time been exposing the short-comings of imported, Western categorizations of local socio-economic conflicts as ones that can be studied through the lens of a state versus private enterprise distinction. ${ }^{174}$ Such examples point to the need to carefully trace the distortions arising from a transposition onto the transnational level of particular, influential national and local regulatory 'experiences,' for example, of Western nation-state transformations that

170. See generally WILLKE, supra note 113; Karl-Heinz Ladeur, Globalization and the Conversion of Democracy to Polycentric Networks: Can Democracy Survive the End of the Nation State?, in PUblic Governance IN THE AGE of Globalization 89 (Karl-Heinz Ladeur ed., 2004); Orly Lobel, The Renew Deal: The Fall of Regulation and the Rise of Governance in Contemporary Legal Thought, 89 MINN. L. REV. 342 (2004).

171. For a striking example of a case where the Court arguably ought to have incorporated a considerably deeper and more researched knowledge basis, see Flomo v. Firestone Natural Rubber Co. (Flomo II), 645 F.3d 1013 (7th Cir. 2011).

172. Flomo v. Firestone, supra note 171.

173. See, e.g., JAMES L. Sibley AND D. WESTERMANN, LiberLA-OLd AND New. A STUDY OF ITS SOCIAL AND ECONOMIC BACKGROUND WITH POSSIBILITIES OF DEVELOPMENT 102-07 (1928) (albeit highlighting the positive effects of the employment of "the native" on the rubber plantation); CHARLES MORROW WILSON, LIBERIA 127.46 (1947) (highlighting the tension between the technologically advanced rubber industry and the existing traditional agricultural conditions). "As the growing and processing of rubber became part of the primary economy and social structure of Liberia, the sheer contrast between the technologies of one of the most complex of world industries and the primitive integrity of the black-green African frontier grows even more conspicuous." Id. at 146. For a collection of concise studies of country case studies of employment conditions in developing countries in a context of global multinational operations, see LABOUR RELATIONS IN DEVELOPMENT (Alex E. Fernández Jilberto and Marieke Riethof, eds. 2002) (with examples from Eastern Europe, Latin America, and South-East Asia).

174. See e.g., Charis Kamphuis, Canadian Mining Companies and Domestic Law Reform: A Critical-Legal Account 145613 GERMAN LAW JouRnAL (2012); Sara Seck, Home State Regulation of Environmental Human Rights Harms As Transnational Private Regulatory Governance, 13 GERMAN LAW JOURNAL 1360 (2012). 
have been studied through the lens of a state-market dualism, the constitutional embrace of freedom of contract and property rights, as well as the received wisdom of historical trajectories of nationalization and privatization. ${ }^{175}$ Instead of taking the narrative of the state's function to consist, exclusively, in the promotion of business, as it has become the emblem of global neo-liberalism, ${ }^{176}$ as the blueprint for a global free market society, the challenge is to scrutinize the complex and contested role of the state in a knowledge society ${ }^{177}$ to identify its growing dependency on societal knowledge and input. Contrasting this transformation of the epistemological basis of contemporary Western governance structures with Southern epistemologies and experiences with state formation and rights consolidation ${ }^{178}$ is central to such an undertaking. Anthropological research points to exactly these frontiers, ${ }^{179}$ at which scholars and those conducting ethnographic field studies must hope to encounter lawyers, so that in such collaboration it might become possible to get a clearer picture of what actually lies 'behind a case,' while resisting inadequate categorizations as well as universalizing modernization narratives. ${ }^{180}$

175. See generally Benedict Kingsbury et al., The Emergence of Global Administrative Law, 68 LAW \& CONTEMP. PROBS. 15 (2005).

176. Colin Crouch, The Strange Non-Death of Neoliberalism 7 (2011).

177. See generally Dominique Pestre, Science, Society and Politics: Knowledge SOCIETIES FROM AN Historical PERSPECTIVE: REPORT TO THE SCIENCE, ECONOMY AND SOCIETY DIRECTORATE AT THE EUROPEAN COMMISSION (2007), available at http:/ec.europa.eu/research/science-society/document_library/pdf_06/historicalperspectives_en.pdf; Karl-Heinz Ladeur, Constitutionalism and the State of the 'Society of Networks': The Design of a New 'Control Project' for a Fragmented Legal System, 2 Transnat'L Legal TheORY 463 (2011); Dick Pels, Mixing Metaphors: Politics or Economics of Knowledge?, in SOCIETY AND KNOWLEDGE, supra note 113, at 269.

178. See, e.g., CONSTITUTIONALISM OF THE GLOBAL SOUTH: THE ACTIVIST TRIBUNALS OF INDIA, SOUTH AFRICA, AND COLOMBIA, supra note 168; Issa G. Shivji, Constructing a New Rights Regime: Promises, Problems and Prospects, 8 Soc. \& LEGAL STUD. 253 (1999).

179. See e.g., TRANSFORMING ETHNOGRAPHIC KNOWLEDGE (Rebecca Hardin \& Kamari Maxine Clarke, eds. 2012); MARGARET KOVACH, INDIGENOUS METHOdOLOGIES. CHARACTERISTICS, CONVERSATIONS, AND CONTEXTS (2009); ETHNOGRAPHIC FIELDWORK. AN ANTHRopological READER (2nd ed., Antonius C.G.M. Robben \& Jeffrey A. Sluka, eds. 2012).

180. See generally COMAROFF \& ComAROFF, supra note 89; Santos, supra note 89. 
